PII S0016-7037(96)00067-1

\title{
Recrystallized impact glasses of the Onaping Formation and the Sudbury Igneous Complex, Sudbury Structure, Ontario, Canada
}

\author{
B. O. DRESSLeR, ${ }^{1}$ T. Weiser, ${ }^{2}$ and P. BROCKMEYER ${ }^{3 * *}$ \\ 'Lunar and Planetary Institute, 3600 Bay Area Boulevard, Houston, TX 77058, USA \\ 2Bundesanstalt für Geowissenschaften und Rohstoffe, Stille Weg 2, 30631 Hannover, Germany \\ 'Institut für Planetologie, Universität Münster, Wilhelm Klemm Strasse 10, 48149 Münster, Germany
}

(Received October 3, 1995; accepted in revised form February 21, 1996)

\begin{abstract}
The origin of the Sudbury Structure and of the associated heterolithic breccias of the Onaping Formation and the Sudbury Igneous Complex have been controversial. While an impact origin of the structure has gained wide acceptance over the last 15 years, the origin of the recrystallized Onaping Formation glasses and of the igneous complex is still being debated. Recently the interpretation of the breccias of the Onaping Formation as suevitic fall-back impact breccias has been challenged. The igneous complex is interpreted either as a differentiated impact melt sheet or as a combination of an upper impact melt represented by the granophyre, and a lower, impact-triggered magmatic body consisting of the norite-sublayer formations.

The Onaping Formation contains glasses as fluidal and nonfluidal fragments of various shapes and sizes. They are recrystallized, and our research indicates that they are petrographically heterogeneous and span a wide range of chemical compositions. These characteristics are not known from glasses of volcanic deposits. This suggests an origin by shock vitrification, an interpretation consistent with their association with numerous and varied country rock clasts that exhibit microscopic shock metamorphic features. The recrystallized glass fragments represent individual solid-state and liquid-state vitrified rocks or relatively small melt pods.

The basal member lies beneath the Gray and Black members of the Onaping Formation and, where not metamorphic, has an igneous matrix. Igneous-textured melt bodies occur in the upper two members and above the Basal Member. A comparison of the chemical compositions of recrystallized glasses and of the matrices of the Basal Member and the melt bodies with the components and the bulk composition of the igneous complex is inconclusive as to the origin of the igneous complex. Basal Member matrix and Melt Bodies, on average, are chemically similar to the granophyre of the Sudbury Igneous Complex. suggesting that they are genetically related. Our chemical results allow interpretation of the entire igneous complex as a differentiated impact melt. However, they are also consistent with the granophyre alone being the impact melt and the norite and quartz gabbro beneath it representing an impact-triggered magmatic body. This interpretation is preferred, as it is consistent with a number of field observations. A re-evaluation and extension of structural field studies and of geochemical data, as well as a systematic study of the contact relationships of the various igneous phases of the igneous complex, are needed to establish a Sudbury impact model consistent with all data and observations.
\end{abstract}

\section{INTRODUCTION}

The Sudbury Structure, Ontario, Canada, is $1.85 \mathrm{Ga}$ old (Krogh et al., 1984) and is known for one of the largest Ni$\mathrm{Cu}-\mathrm{PGE}$ reserves on earth; its origin, by either magmatic or impact processes, has been discussed for more than a century. However, since the discovery of shatter cones in the footwall rocks (Dietz, 1964) around the Sudbury Igneous Complex (SIC), evidence favoring an impact origin of the structure has mounted. Shock metamorphic features in footwall rocks (Dence, 1972; Dressler, 1984; Dressler et al., 1987; Müller-Mohr, 1992) and the strong brecciation of these rocks up to a distance of about $80 \mathrm{~km}$ north of the SIC (Dressler, 1984; Peredery and Morrison, 1984; Dressler et al., 1987; Thompson and Spray, 1994) support an impact origin of the structure. Shatter cones occur all around the SIC and up to $17 \mathrm{~km}$ away from it (Guy-Bray and Geological Staff, 1966; Dressler, 1984). The heterolithic breccias of the

\footnotetext{
* Present address: Heekweg 79, 48161 Münster, Germany.
}

Onaping Formation (French, 1967, 1968, 1972; Peredery, 1972a,b; Muir and Peredery, 1984; Brockmeyer, 1990; Avermann, 1992; Avermann and Brockmeyer, 1992) also exhibit unequivocal shock metamorphic features, such as planar micro-deformation features in rock-forming minerals, and contain recrystallized glasses interpreted as the product of shock metamorphism. All this is convincing evidence for an impact origin of the Sudbury Structure. However, there are features that until recently were interpreted as possibly providing evidence for an endogenic origin. Amongst them are the elliptical shape of the SIC (Card and Hutchinson, 1972; Muir, 1984) - most impact structures on Earth and the other planets of the Solar System are more or less circular-and the physical, volcanogenic character of the heterolithic breccias of the Onaping Formation (Muir, 1984; Stevenson, 1990). The present non-circular shape of the SIC, however, can be attributed to post-Sudbury event tectonic deformation (Peredery and Morrison, 1984; Shanks and Schwerdtner, 1991; Milkereit et al., 1992; Cowan and Schwerdtner, 1994; Wu et al., 1994). Recently, the impact origin of the hetero- 
lithic breccias of the Onaping Formation has been challenged by Gibbins (1994) and Gibbins et al. (1994) because of their similarity to volcanic pyroclastic deposits. According to Gibbins ( 1994 ), the deposition of the Onaping Formation was caused by fragmentation of "mell" upon repeated interaction with water. Impact fallback breccias were either deposited beneath the Onaping Formation and subsequently assimilated by the basal intrusion (basal member, see below) or by the SIC, or were never actually deposited within the Sudbury Basin.

In the present paper we provide evidence for an impact origin of the recrystallized glasses of the Onaping Formation. (All glasses of the Onaping Formation are recrystallized. The term "glass" in this publication refers to the original state of the analyzed material.) We compare the chemical composition of these glasses with those of various impact melt breccias within the Onaping Formation and with the rocks of the SIC. We believe that our results demonstrate that the glasses were produced by shock melting, as advocated earlier in the history of investigations of the Onaping Formation (Peredery, 1972a,b), and that they mainly represent individual vitrified rocks, relatively small individual melt bodies, fragmented melt bodies, and heterogeneous melt breccias. They were not derived from a large, homogeneous impact melt sheet, which at Sudbury is possibly represented by all or part of the SIC. By comparing the individual and average chemical compositions of glass fragments and the average composition of melt bodies and melt matrix of the Basal Member of the Onaping Formation with the bulk composition of the various phases of the SIC we intend to advance our understanding of rock vitrification associated with large-scale impact processes.

\section{GENERAL GEOIOGY OF THF SUDBURY STRUCTURE}

The Sudbury Structure. consisting of the SIC the rocks of the Whitewater Group in the Sudbury Basin, and shock metamorphosed and brecciated footwall rocks underlying the SIC, is located in central Ontario, Canada (Fig. 1). It lies at the present boundary of the Archean Superior Province and the Proterozoic Southern Province of the Canadian Shield. approximately 10 to $30 \mathrm{~km}$ north of the Grenville Province. Gneissic rocks of the Superior Province to the north of the structure are about 2.71 Gat old and pegmatoids spatially associated with these gneisses are about 2,64 Gia old i Krogh et al., 1984). The Proterozoic supracrustal rocks to the south and northeast of the SIC belong to the Huronian Supergroup (about 2.5 to $2.4 \mathrm{Ga}$ old: Krogh et al., 1984). Outliers of these rocks also occur north and west of the SIC and, coupled with the presence of clasts of these rocks in the heterolithic breccias (Onaping formation) in the Sudbury Basin, provide evidence that the region was underlain by these Proterozoic rocks at the time of the Sudbury impact event. The Huronian supracrustal rocks are intruded by igneous rocks, in the south by the Murray and Creighton granitic plutons (about 2.4 to 2.5 Ga old: Frarey et al., 1982: Krogh et al.. 1984, 1996), and all around the SIC by Nipissing gabbros of approximately $2.2 \mathrm{Ga}$ age (Corfu and Andrews, 1986). The Grenville Province is characterized by a last metamorphic event dated 0.9 to $1.0 \mathrm{Ga}$ ago.

The Sudbury Structure, as interpreted today. originally was at least $200-250 \mathrm{~km}$ in diameter (Peredery and Morricon, 1984; Dressler et al., 1987; Grieve et al., 1991), is 1.85 Ga old (Krogh et al.., 1984). has been deformed by SE-NW thrusting (Peredery and Morrison. 1984; Shanks and Schwerdtner. 1991), and according to recent vibroseismic investigations (Milkereit et al.. 1992: Wu ct al., 1994), may have been considerably larger than previously assumed. The SIC is a major component of the structure and is at $27 \mathrm{~km}$ by $60 \mathrm{~km}$ elliptical body consisting from bottom to top of inclusion-rich quart/ diorite (Sublayer), norite, quartz gabbro, and granophyre layers. It is considered a differentiated, crust-contaminated magma (Naldreıt and Hewins, 1984) or a differentiated impact melt body ( Faggart et al., 1985; Grieve el il.. 1991; Deutsch, 1994), or possibly a combination of these two possibilities (Dence. 1972; Shanks et al.. 1990; Chai and Eckslrand. 1993, 1994; Johns and Dressler, 1995). The Ni$\mathrm{Cu}$ orebodies occur in the sublayer, in the footwall rocks immediately beneath it, and in so-called offset dikes of inclusion-rich quart) diorite intruding the footwall rocks in several places around the SIC. Below the SIC and northward up to about $80 \mathrm{~km}$ from it, the Proterozoic and Archean rocks are cut by pseudotachylitic breccias. called "Sudbury Breccias" ( Speers, 1957: Dressler, 1984: Peredery and Morrison, 1984: Müller-Mohr. 1992; Thompson and Spray, 1994; Spray and Thompson. 1995 ) and, up to $10-12 \mathrm{~km}$ north of it, exhibit microscopic shock metamorphic features (Dence, 1972 Dressler, 1984). Shatter cones occur in the footwall rocks around the SIC up to $17 \mathrm{~km}$ away from it (Guy-Bray and Geological Staff, 1966; Dressler. 1984). The Whitewater Group, overlying the SIC in the Sudbury Basin, convists from bottom to top of breccias of the Basal, Gray, and Black members of the Onaping Formation (about $1600 \mathrm{~m}$ thick, Peredery, 1972a,b; Muir and Peredery, 1984; Brockmeyer, 1990: Avermann, 1992: Avermann and Brockmeyer. 1992, the mudstones of the Onwatin Formation $(600) \mathrm{m}$ thick. Rousell 1984), and the turbiditic wackes of the Chelmsford Formation ( 850 m preserved thickmess. Rousell, 1984 l.

The Onaping Formation has been alternatively interprefed as lithified glowing avalanches, ash flows, ash flow tuffs and lavas (Thomson, 1957: Williams. 1957; Stevenson, 1972, 199(1), explosion breccias, caldera collapse breccias, lapilli tuffs, tuffs, and welded tuffs (Muir. 1984 I. or impact fall-back or impact crater-filling breccias and impact melt fragments (French, 1967, 1968. 1972; Dence. 1972: Peredery, 1972a,b. Brockmeyer. 1990; Avermann, 1992; Grieve et al., 1991). The Formation is stratified and can be subdivided from bottom to top into it Basal Member, a Gray Member, and a Black Member. A fourth. hut nonstratigraphic member comprises the soscalled Melt Bodies, which according to Muir and Peredery (1984) occur mainly between the Basal and Gray members, but also within the upper two members of the formation. Brockmeyer's (199(J) Green Member. equivalent 1o the chlorite shard horizon of the older literature (Muir and Peredery, 1984), is located at the Gray-Black Member interface. The basal member of the northern and eastern Sudbury Structure (North Range and East Range) is distinctly different from that of the South Range. In the north and the east. this Member contains a wide variety of fragments derived from the Proterozoic and Archeatn larget rocks set in at very tine-grained matrix and was interpreted by Brockmeyer (1990) to represent impat melt breccia. In the south. the Basal Member was termed quartrite breccia by Stevenson (1960, 1961); it consists mainly of large clasts of quarty arenite and arkose, hesides very minor quartz-pebhly arkose and Proterozoic granite fragments. The matrix of the quartcite breccia is strongly tecrystallized and may have been either a melted or a clastic malrix. Peredery $11972 \mathrm{~b})$ and Dressler et al. (1987) compared the breccia stratigraphy of the Onaping formation with that of the Ries impact structure in Germany. The quartzite breccia consists of fragments derived from the upper target stratigraphy and. assuming that the matrix of the quartzite breccia originally had been clastic, the breccia may very well have been a "Bunte Breccia" deposit, known to occur in the megablock zone and outside the morphological crater of the Ries (Huittner, 1969; Engelhardt, 1990). If this interpretation is correct, the quartzite breccia had been deposited outside the transient crater-assumed to have beell atbout 100 $\mathrm{km}$ in diameter---and brought into its present position by northwestward thrusting which included the South Range SIC. North of the SIC, the quartzite breccia has been eroded away, if it was ever present there. Nowhere dows the Basal Member contain any recrys tallized glass fragments, which are common in both the Gray. Green, and Black Members. Shock metamorphic features (see below) are present in all breccias of the Onaping Formation, with the exception of shock features in the South Range where they have been obliterated by regional metamorphism and recrystallization. As a Bunte Breccia deposit. the sedimentary rock fragments of the quartzite breccia would have been devoid of diaplectic glasses and other 

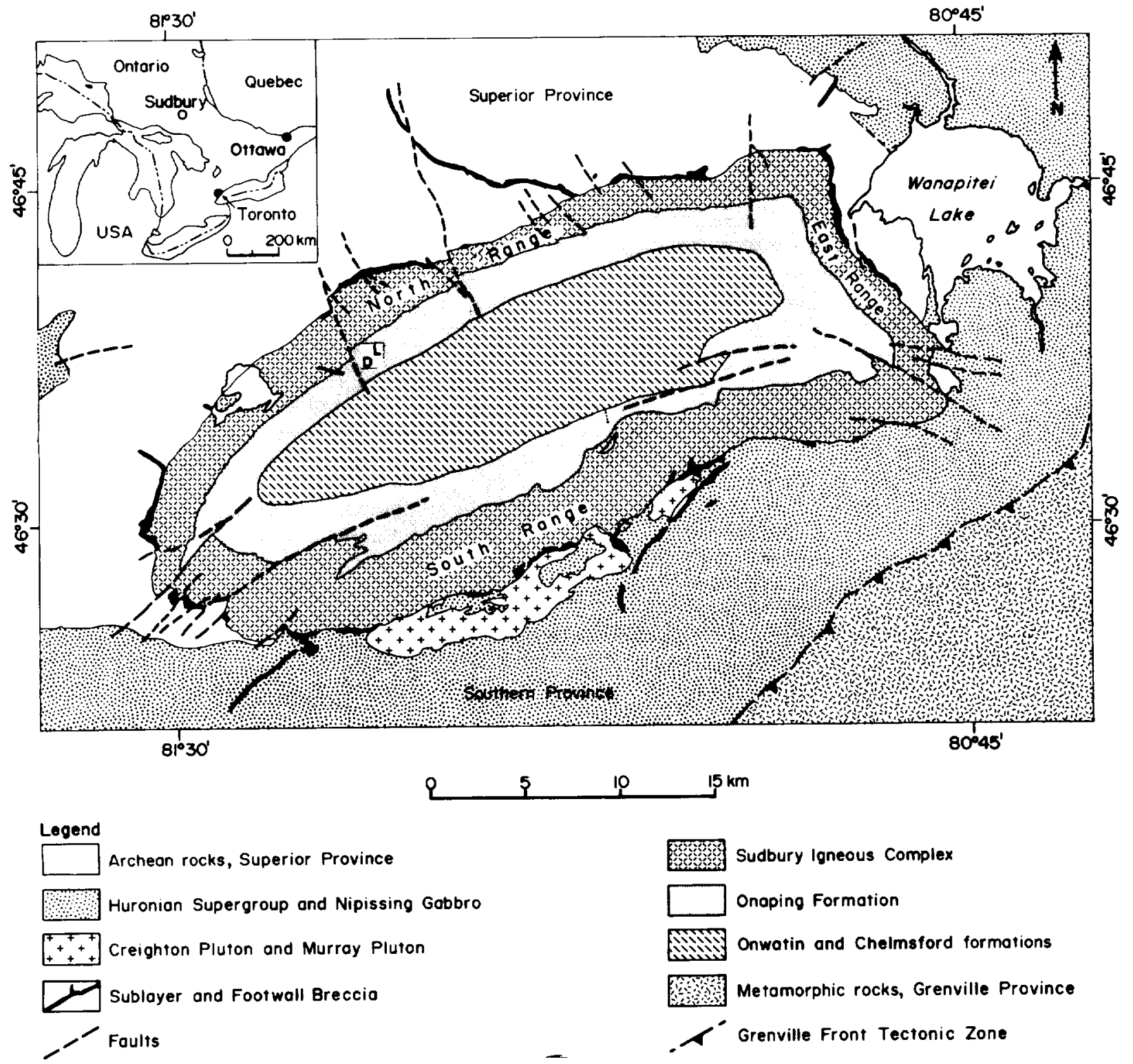

FIG. 1. General geology of the Sudbury Structure, Ontario, Canada (from Dressler et al., 1991). D-L: Location of Dowling and Levack townships, from where the samples investigated by electron microprobe were obtained.

features representing strong shock. In contrast, both the Gray and Black members are characterized by the presence of recrystallized glass fragments ranging in size from smaller than one millimeter to several centimeters, and locally $10 \mathrm{~m}$. In an impact scenario they represent suevite and redeposited suevite, respectively. Peredery (1972b) proposed rapid tsunami-wave action to account for the redeposited Black Member debris. At higher stratigraphic levels, the member exhibits planar bedding and is gradationally and conformably overlain by mudstones of the Onwatin Formation. At the type location of the Ries crater, suevite is defined as a heterolithic clastic matrix breccia consisting of shock metamorphosed rock and mineral fragments and impact glass fragments of various sizes. The Black Member of the Onaping Formation contains 0.2 to $0.75 \%$ carbon in the matrix (Burrows and Rickaby, 1930; Stevenson, 1972) which is responsible for the color and name of the member. Fullerenes have been discovered by Becker et al. (1994) in the Black Member. Brockmeyer's (1990) Green Member, in our opinion, is a melt deposit derived from a hot gas-melt particle fireball fall-back ejecta collapsed from high altitudes onto the gray member suevite before redeposition of the Black Member suevite. The chloritic "shards" in it may represent collapsed vesicles that have shard-like shapes (Brockmeyer, 1990). The interested reader is referred to Pye et al. (1994) and Dressler et al. (1991) for detailed treatises of the geology and ore deposits of the Sudbury Structure.

\section{SHOCK METAMORPHISM OF ROCKS OF THE SUDBURY STRUCTURE}

Shock metamorphic features are formed when two solid bodies collide at hypersonic velocities. On Earth, shock metamorphic features have been recognized in meteorites, in basement target rocks of impact craters, in the breccias deposited in impact craters, and in the ballistic ejecta surrounding craters (French and Short, 1968). In the case of 
large impact events, shock metamorphosed mineral frag ments may be distributed worldwide and found in specific ejecta horizons, such as at the $\mathrm{K} / \mathrm{T}$ boundary related to the 6.5 Ma old Chicxulub impact event at Yucalan. Mexico (Hildebrand et al., 1991: Sharpton et al.. 1992: Swisher et al., 1992; Krogh et al., 1993). Amongst the most commonly observed shock metamorphic features are fracturing and the development of kink bands in rock-forming minerals, which. by themselves, are not diagnostic shock deformations. However, plastic deformations, such as planar micro-deformation features, deformation bands, mosaicism (i.e.. irregular mineral lattice deformation ), and solid state mineral transformations are indicative of shock and impact. Solid state transformations result in the formation of high pressure mineral phases and diaplectic glasses ("short range order phases"). Very high shock pressures result in the formation of fused. liquid-state mineral and rock glasses. The physical properties of all these features, their significance in geoscience, and their genetic implications have been described in considerable detail by several authors in French and Short (1968), by DeCarli and Milton (1965), Stöffler (1971a,h, 1972, 1974. 1984), French (1966). Engelhardt and Bertsch (1969), Engelhardt and Graup (1977), Arndt et al. (1982). Stöffler and Langenhorst (1994), and Grieve et al. (1996), to list just a few. Planar deformation features in quart/ and feldspar have been observed in the basement rocks of the SIC (Dence, 1972: Dressler, 1984) and in mineral and rock fragments of the Onaping Formation (French, 1967, 1968. 1972; Peredery, 1972a,b; Muir and Peredery, 1984: Brockmeyer, 1990; Avermann. 1992; Avermann and Brockmeyer, 1992).

Recrystallized impact glasses, in isolation and as fragments in breccias, are not easily distinguished from endogenic, i.e., volcanic, glasses. Their association with a wide range of shock-deformed country rock fragments, is however, good evidence for their origin by impact. The glasses of the Onaping Formation - if of shock metamorphic origin should represent solid state mineral and rock transformation and/or fused, liquid-state glasses formed through shock thermal melting of minerals and rocks. Diaplectic rock glasses are internally heterogeneous, spatially mimicking the composition of polymineralic rocks. However, diaplectic glasses derived from very fine-grained volcanic larget rocks may be indistinguishable from volcanic glasses or shock fused, liquid-state glasses. Shock-fused glasses are either homogeneous or heterogeneous depending on the degree of mixing of components during the shock vitrification process. Thus, we propose that the occurrence of diaplectic, glassy fragments alone, or in association with liquid-state glass fragments with a considerable range of compositions, in a breccia is evidence for an impact origin of the breccia. Volcanic, pyroclastic deposits contain glass fragments that, in general, have a more restricted range of glass compositions than impact breccia deposits. Nonetheless, volcanic deposits containing rhyolitic to basaltic glass framents have been observed (e.g., Sigurdson and Sparks, 1981). Equally, in an impact scenario a homogeneous target rock may result in liquid-state glasses of a relatively restricted composition. This has been reported from the Ries impact crater, where liquid-state glass fragments in suevite all have more or less the same composition (Hörz, 196.5: Engelhardt. 1972). Geo- chemical evidence alone may not always be sufficient to distinguish belween glatsses of volcanic or impact origin.

A tariety of texturally, mineralogically, and, therefore, also chemicatly difterent recrystallized glass fragments of the Onaping Formation are recognizable with the optical microscope. For example, glass which is completely replaced by chlorite may represent a target rock geochemically different from light greenish-gray glasses omnipresent in both the Grily and Black members. Texturally the glass fragments are either heterogeneous, featureless, and more or less homogeneous, or exhibit fine laminations suggestive of liquid-state melting and flow. Many glass fragments in the Onaping Formation have shard-like shapes, but features indicative of welding have also been observed (discussion by Muir, in Muir and Peredery. 1984). Shard-like outlines and Huidal textures allow positive identification of glass fragments despite post-impact recrystallization and regional metamorphisn. We have collected our samples from an area in the northern part of the Sudbury Basin (Fig. 1) characterized by low greenschist facies regional metamorphism. Building on our lield and petrographic observations and on those of others (e.g. Peredery, 1972a,b; Muir and Peredery. 1984), we selected a number of specimens for detailed geochemical investigations to test our views on the origin of the glasses of the Onaping Formation.

\section{PETROGRAPHY OF SAMPLES ANALYSED BY MICROPROBE}

A wide variety of rock, mineral, and recrystallized glass fragments occurs in the various units of the Onaping Formation. Their physical characteristics have been described by previous authors, notably by Peredery (1972a) and Muir and Peredery (1984). All units of the Formation contain a variety of rock and mineral fragments, many of which show evidence of shock metamorphism. Recrystallized glass fragments of various sizes. shapes. and compositions occur in the suevitic breceias of the Gray and Black members. The Basal Member is devoid of glass fragments and has a groundmass interpreted by Brockmeyer (1990) to represent an impact melt. The glasses of the Onaping Formation are all recrystallised is they were subjected to post-impact devitrification and low greenschist facies regional metamorphism. A large number of Onaping Formation specimens and thin sections from vamous locations in the Sudbury Basin were investigated by us with the petrographic microscope and allowed us to select representative samples for microprobe analysis. In the following, a brief petrographic description and interpretation of the samples analysed by us with the microprobe are presented.

Sample 34712 is a fluidal glass fragment in a Gray Member sample (Fïg. 2). It contains small quartz, quartz arenite, and mudstone fragments. Most of them are recrystallized. One of the tiny quartz fragments has a corona of chlorite, possibly after pyroxene. Similar coronas are common around fragments in impact melts (e.g. Floran el al.. 1978) indicating chemical disequilibrium between fragment and melt. A $3 \mathrm{~mm}$ large quartz fragment, not shown on Fig. 2 . exhibits wo sets of planar deformations features. Elongate fragnents are flow-iligned. Amygdules (not shown on Fig. 2) are present. are up to about $1 \mathrm{~mm}$ in diameter, and are filled either with chlorite or with chlorite, actinolite, and spaque minerals. The very fine-grained. felt-like groundmass is yuartzofeldspathic and contains tiny, light greenish needles and liaker optically determined as amphibole. The 


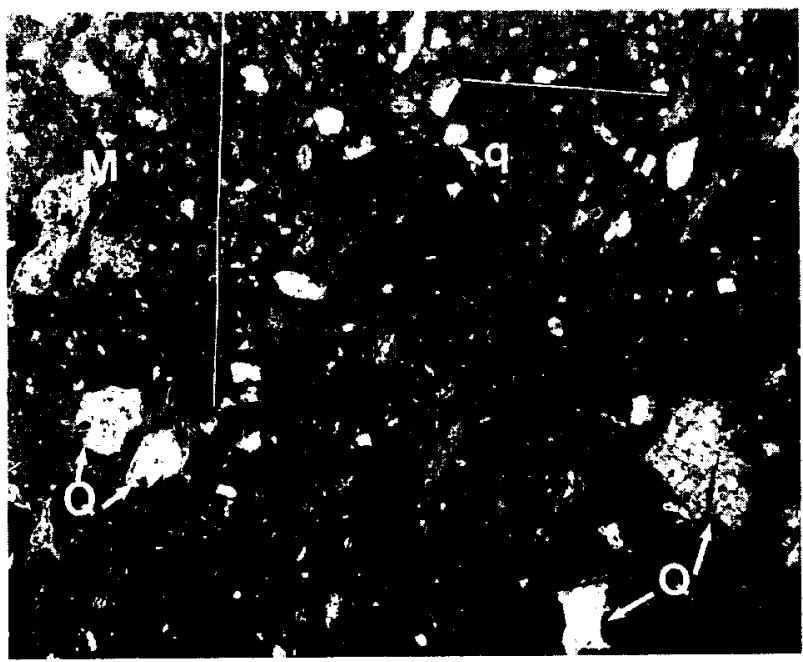

FIci, 2. Fluiditl Griay Member glass (sample 34712) with two microprobe protiles. Q: Quart/ atrenite fragment. M: Mudstone fragment. y: Quary fragment with corona. See also description of sample in text. Compare with Fig. 10 and Tables 1 and 2. Length of photograph is $1.9 \mathrm{~cm}$. Plance polarized light.

texture of the groundmass is reminiscent of that of devitrified glass. The amphibole possibly represents pseudomorphs after pyroxene microlites. The fluidal texture of sample 34712 ( see alignment of elongate fragments in Fig. 2) is that of a liquid-state glass. Two profiles were measured in this sample (Fig. 2), one consisting of 30) points over $5.2 \mathrm{~mm}$, the other of 50 points over $10.0 \mathrm{~mm}$.

Sample 3471.3 is of the Gray Member (Fig. 3). The analysed fluidal. liquid-stale glass fragment is embedded in a breccia consisting of a variety of rock. mineral and glass fragments. It contains two rock clasts, one a quartz wacke, the other one a very tine-grained mudstone. The clasts in the wacke are angular to subrounded and consist of quartz that exhibits up to two sets of decorated planar deformation features per grain. Tiny, angular quartz grains and clasts of recrystallized quartz. commonly lensoid or elongated parallel to the lamination, are abundant in the glass. Flow lines wrap around the two larger, metisedimentary clasts. The glass groundmass of sample 34713 is very tine grained and similar to that of sample 34712 , described above. One 30 point, $5.0 \mathrm{~mm}$ long profile was analyzed across this glass fragment.

Two recrystallized, fluidal glass fragments of Gray Member sample 34714 were analyzed ( $\mathrm{Fig}$. 4). They are embedded in a breccia consisting of a variety of mineral, rock, and glass fragments. One of the profiles runs across one piece of a large. broken fluidal fragment, consists of 30 points and is $4.0 \mathrm{~mm}$ long. Tiny quart $\angle$ and plagioclase fragments are included in the dense recrystallized glass. The other glass fragment from this analysed sample is broken into three pieces. and contains a recrystallized wacke clast, a mudstone clast, and fragments of polygonal quartz. The profile across this fragment is $2.9 \mathrm{~mm}$ long and consists of 30 points. It was analysed with both a focused $0.5 \mu \mathrm{m}$ and a defocused $15 \times 15 \mu \mathrm{m}$ electron beam. The fluidal texture, the shapes. and the fractures of both analysed glass fragments suggest that the fragments represent liquid-state glasses and that they were solidified when they were incorporated into the breccial deposit as they broke apart during the depositional process.

Sample 34715 is a recrystallized glass fragment of the Gray Member and is set in a breccia of mineral. rock and glass fragments (Fig 5) It is oval. fluidal, i.e. liquid-state, and contains two small inclusions. One of them is dark colored and aphanitic, the other light colored, very tine grained, and crystalline. The recrystallized glass is too tine grained for reliable optical mineral delermination. The shapes of the analysed fragment and that of other fragments in Fig. 5 suggest that the fragments were solidified prior to deposition. One analytical profile was analysed across the sample, boh with a fo-

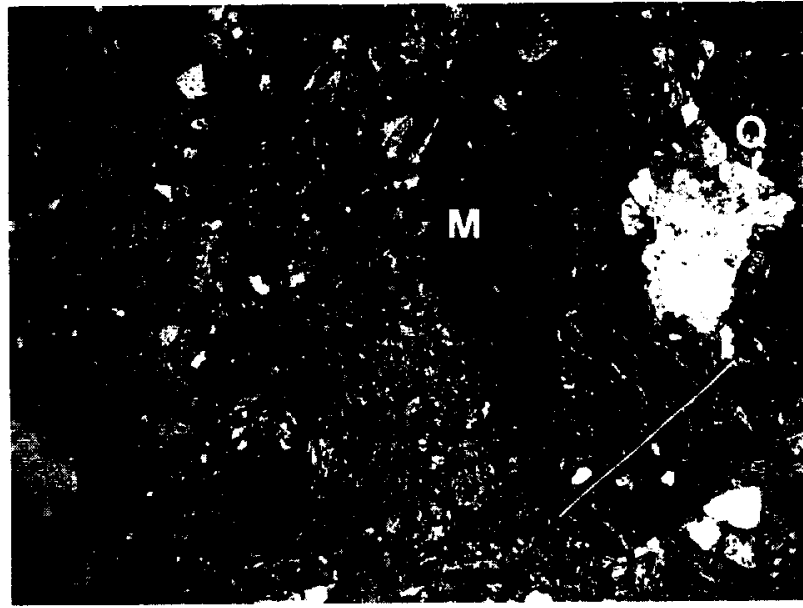

Fici. 3. Fluidal Galy Member glass 1 sample 34713) with one microprobe profile. Q: Quart\% wathe fragment. M: Mudstone fragment. See also description of sample in text. (ompare with Table 2. Length of pholegraph is $1.7 \mathrm{~cm}$. Pline polatriad light.

cused and at defocused electron beam. The protile is $4 \mathrm{~mm}$ long and contains 30 points.

Sample 34716 is a glas fragment in a Gray Member specimen (Fig. 6). is irregularly shaped, fluidal, and contains many small inclusions aligned parallel to the fluidal texture. The fragment is folded and set in at brecciat consinting of mineral. rock, and glass fragments. Not shown on Fig. 6 is at thin, sinuous and dike-like feature extending from the fragment into the breccia suggesting that this liquid-state glass fragment wat nol solidilied prior to deposition. Faintly visible, oval shape's in the reerystallized glass groundmass are suggestive of recrystallized anygdules. They are somewhat elongate parallel to the lanination of the glass. Two profiles were analysed. one of them with both a focused and unfocused electron beam. One of the profiles is $5 \mathrm{~mm}$ long and has 30 points. whereas the other is $5.5 \mathrm{~mm}$ long with 50 points.

Sample 34717 is of the Graly Member (Fig. 7). The analysed glass fragment is set in a brecia of rock. mineral, and fluidal and

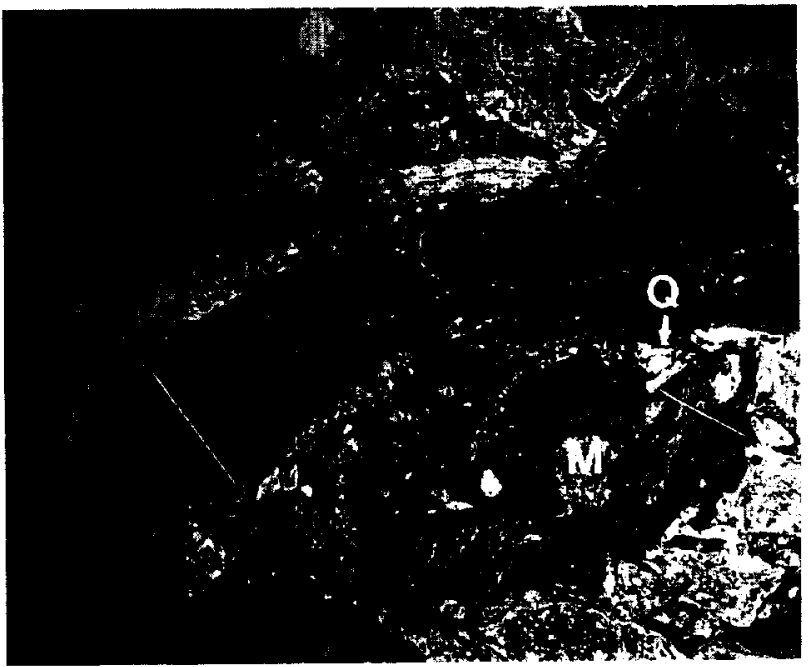

FIG 4 Gray Member glasses (sample 3.4714 ) with one microprobe profile each. Q: Wacke fragment. M: Mudsione fragment. See also description of sample in text. Compare with Table 2. Length of photograph is $2.3 \mathrm{~cm}$. Plane polarized light 


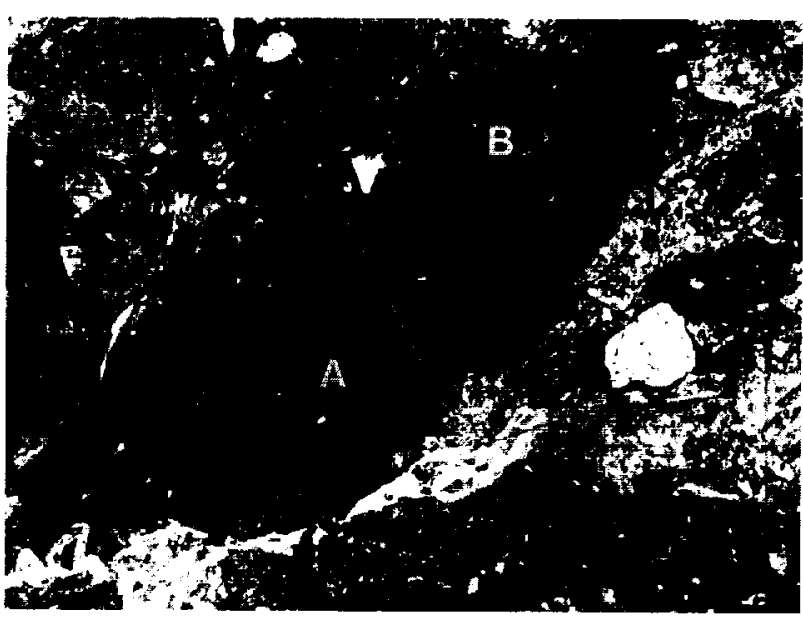

Fici. 5. Fluidal Gray Member glass (sample 34715) with one microprobe profile. A: Dark, aphanitic inclusion. B: Light colored, crystalline inclusion. See also description of sample in text. Compare with Tathe 2. Length of photograph is $1.4 \mathrm{~cm}$. Plane polarized light.

nontluidal glass hagments. It contains numerous inclusions. One of two relatively large ones is very fine grained. rectangular in shape, and possibly is a metavoleanic rock. The other one is a fine-grained, quartz-rich, actinolite-bearing rock. Near the maroin the liquid-state fragment is distinctly fluidal. Two microprobe protiles, one across the whole fragment, the other halfway across, were analysed. Both consist of 20 points. One is $6 \mathrm{~mm}$, the other $2.5 \mathrm{~mm}$, long.

The fluidal glass fragment $4.30 \mathrm{~F}$ of the Graly Momber contains angular to subrounded quarts clasts and one small actinolite fragment. The quartz in places exhibits planar deformation features. Quartzofeldspathic rock clasts also occur. Faint oval shapes in the glass are suggestive of amygdules. Fine actinolite or pyroxene needles, too small for proper microscopic identification. atre reminiscent of devitrification features. Amygdules and fluidal texture are characteristics of a liquid-state glass. A total of fifty randimmly distributed point analyses were performed.

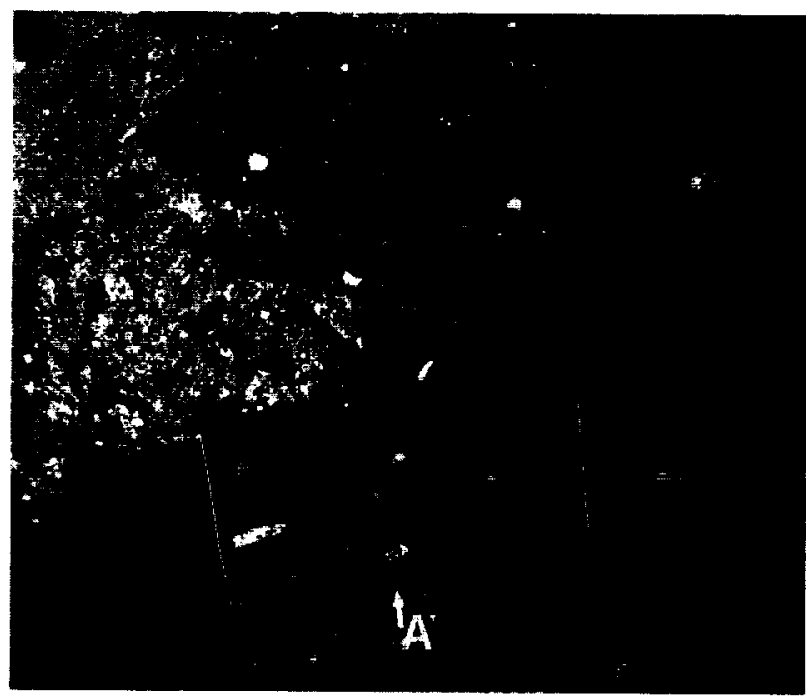

Firi. 6. Fluidal Gray Member glass (sample 34716) with two microprobe protiles. Sec also description of sample in text. A: Recrystallized amgdules? Compare with Table 2. Length of photograph is $2.4 \mathrm{~cm}$. Plane polarized light.

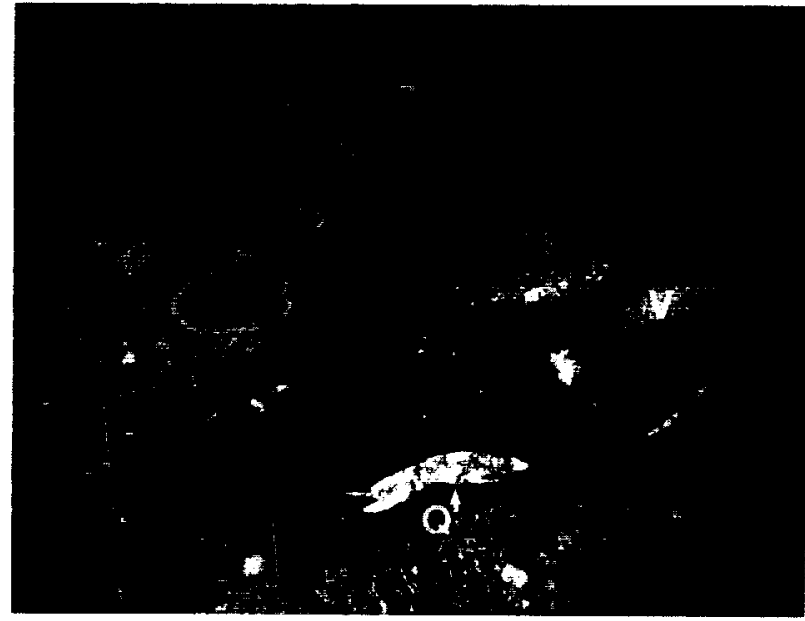

Firi. 7. Fluidal Gray Member glass (sample 34717) with two microprobe profiles. V: Melavolcanic rock fragment? Q: Quart\%rich, actinolite-hearing rock. See also description of sample in text. Compare with Fig. II and Table 2. Length of photograph is $3.0 \mathrm{~cm}$. Plane polarized light.

Fluidal, i.e., liquid-state, glass fragment 93-02-Aii of the Gray Member contains angular quartz clasts and fragments of a quartzrich metasediment. It is about $0.3 \mathrm{~cm}$ by $1.2 \mathrm{~cm}$ in size and set in a typical gray member breccia of mineral, rock, and glass fragments. It is microscopically similar 10 sample 34715 (Fig. 51. A total of eighty-five randomly distributed point analyses were obtained from this fragment.

The analysed tluidal glass fragment 93-(03 of the Gray Member is about $1 \mathrm{~cm}$ by $3 \mathrm{~cm}$ in size. tabular, and similar in shape and microscopic appearance to sample 34717 (Fig. 7). It contains quartz. clasts, quartz arenite clasts, chloritized clasts, and mudstone fragments consisting of quarty and chlorite, possibly after biotite. These inclusions in the glass are either angular in shape or strongly elongated parallel to the fluidal texture of the liquid-state glass. 101 randomly distributed point analyses were performed on this fragment.

Glass fragment 5P83-01, in a Gray Member breccia of mineral, rock and glass fragments, is quartzofeldspathic and exhibits recrystallized quartz grains and weakly preserved spheroids (Fig. 8), It is not fluidal and resembles strongly shocked, almost completely vitrified, diaplectic quartz arenite or arkose. common in suevite of the Wanapitei impact crater east of the SIC. This $37 \mathrm{Ma}$ impact structure is characterized by targets rocks that in part were the same as those of the Sudbury Structure (Dressler et al., 1996). The microprobe profile across the analysed glass fragment is $2.1 \mathrm{~mm}$ long and 30 point analyses at equal distances were measured.

Fragment 110-10 is a nonfluidal, partly chloritized glass (Fig. 9). It occurs in a typical C-bearing Black Member breccia of mineral, rock, and glass fragments. Tiny, angular quartz fragments are set in the chlorite near the microprobe profile. The angular, clastic shapes of the quart $z$ fragments possibly are an indication that fragment 110 10 represents a liquid-state. and not a diaplectic glass. 60 point analyses were performed along a $1 \mathrm{~mm}$ long profile. The large fragment in the center of Fig. 9 may represent diaplectic glass or a little shocked target rock. It exhibits a texture reminiscent of that of an igneous rock and contains euhedral plagioclase. The remainder of the fragment is mainly chlorite and actinolite. Parts of the euhedral plagioclase is replaced by fine-grained epidote. The remainder is relatively unaltered. and exhibits planar fractures or is extremely fine grained and recrystallized.

\section{MICROPROBE ANALYTICAI METHODS AND RESUITS}

Peredery (1972a,b) analyzed a number of fluidal, diaplectic, and chloritized shards of the Onaping Formation that 


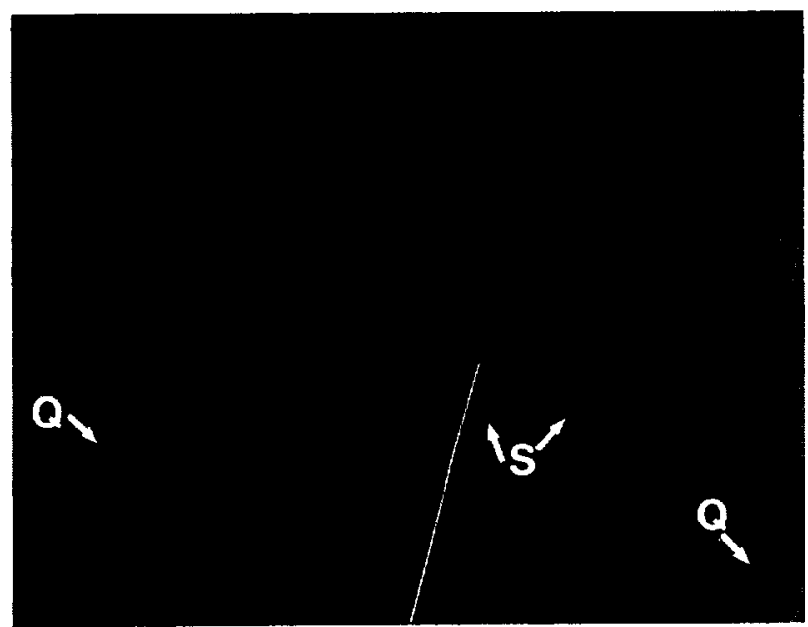

Fig. 8. Gray Member glass ( sample 5P 83-01) with one microprobe profile. S: Recrystallized spheroids. Q: Recrystallized quartz grains. See also description of sample in text. Compare with Table 2. Length of photograph is $6.5 \mathrm{~mm}$. Plane polarized light.

represent a wide array of compositions. For example he reported that $\mathrm{SiO}_{2}$ ranges from about 52 to $69 \mathrm{wt} \%$ and $\mathrm{Al}_{2} \mathrm{O}_{3}$ from about 3 to $20 \mathrm{wt} \%$. In total he carried out sixteen analyses on diaplectic and twenty on fluidal, liquid stage glasises.

The present study includes a microprobe investigation of about fifteen glass fragments. They are described above and shown in the photomicrographs of Figs. 2-9. They represent a relatively small, but representative number of fragments and were selected from a large number of microscopically studied samples. About 700 microprobe analyses were carried out on them. All samples are derived from an area in Dowling and Levack townships in the northwestern Sudbury Basin (Fig. 1). Analyses were carried out with the CAMEBAX Microbeam (CAMECA Instr.) microprobe of the Federal Institute for Geoscience and Natural Resources in Hannover, Germany. Point wavelength dispersive analyses of $\mathrm{Si}, \mathrm{Ti}, \mathrm{Al}, \mathrm{Cr}, \mathrm{Fe}, \mathrm{Mn}, \mathrm{Mg}, \mathrm{Ca}, \mathrm{Na}$, and $\mathrm{K}$ were conducted with a $0.5 \mu \mathrm{m}$ focused beam or a $15 \times 15$ $\mu \mathrm{m}$ square scan area was analysed with defocused circular beam, applying a $15 \mathrm{kV}$ accelerating voltage and a $10 \mathrm{nA}$ specimen current. The measuring time was $10 \mathrm{~s}$. As standards we used albite ( $\mathrm{Si}, \mathrm{Na}$ ), orthoclase (K), andradite (Ca), hematite ( $\mathrm{Fe})$, synthetic $\mathrm{Al}_{2} \mathrm{O}_{3}$ ( $\mathrm{Al}$ ), synthetic $\mathrm{MnTiO}_{3}(\mathrm{Mn}, \mathrm{Ti})$, synthetic $\mathrm{Cr}_{2} \mathrm{O}_{3}(\mathrm{Cr})$, and synthetic $\mathrm{MgO}(\mathrm{Mg})$. One or two profiles were analysed across each glass fragment. Three fragments were analysed at randomly distributed points. Up to 60 points per profile and up to about 100 randomly distributed point analyses were obtained per glass fragment. Three of the profiles were repeated with a defocused electron beam. We carefully selected microprobe traverses to avoid analyzing clasts in cluded in the glass. We believe that the effects of postdeposition alteration are minimal, at least in samples obtained from the Gray Member, from where most our samples were obtained. Silicification, carbonatization, and other alteration effects advocated by Gibbins (1994) to account for the variability of the chemical composition of the various components of the Onaping Formation, if they had been active at all, would have aflected all glass, mineral and rock fragments in the breccias leading to more homogeneous chemical compositions of the glass fragments than observed. Chloritization, however, is common, especially in the Black Member breccias. We helieve that it affected mainly rocks of basic chemical composition. A considerable number of published whole-rock analytical results and several published microprobe analyses have also been used in our study. They substantiate our interpretations. Sources of these earlier data are noted in the legend to Fig. 12 ( see below). Some of the point-analytical results are plotted in Figs, 10 and 11 and show a wide range of compositions. For example, $\mathrm{SiO}_{2}$ in protile 1 of sample 34712 (Fig. 10) ranges from about 28 to $98 \mathrm{wl} \%$. FeO from almost zero to $26 \mathrm{wt} \%$, and $\mathrm{Al}_{2} \mathrm{O}_{3}$ from +10 more than $20 \mathrm{wt} \%$. Profiles obtained from other samples show similar ranges, but are not presented here.

The numerical results of sample 34712 are presented in table format (Table 1). (Numerical results of other samples and their graphical representations may be requested from B. O. Dressler.) The point analyses are interpreted to represent the minerals listed in the table. Relicts of unmetamorphosed pyroxene, possibly from the target rock or originally formed through devitrification, are present.

Table 2 lists the results for all the Gray Member samples studied by us. The high standard deviations reflect compositional inhomogeneity of the various glass fragments along the optically clast-free profiles measured. The average values of the chemical analyses of points are taken as an approximation of the bulk composition of the recrystallized glass fragments. The analyses show a wide range of bulk compositions. For example, $\mathrm{SiO}_{2}$ ranges from about 54 to 72 wt \%: $\mathrm{Al}_{2} \mathrm{O}_{3}$ from 10.75 to $1.5 .42 \mathrm{wt} \%$, and $\mathrm{FeO}$ from 0.03 to 9.86 wt $\%$. In sample 34712 , most elements in one profile have

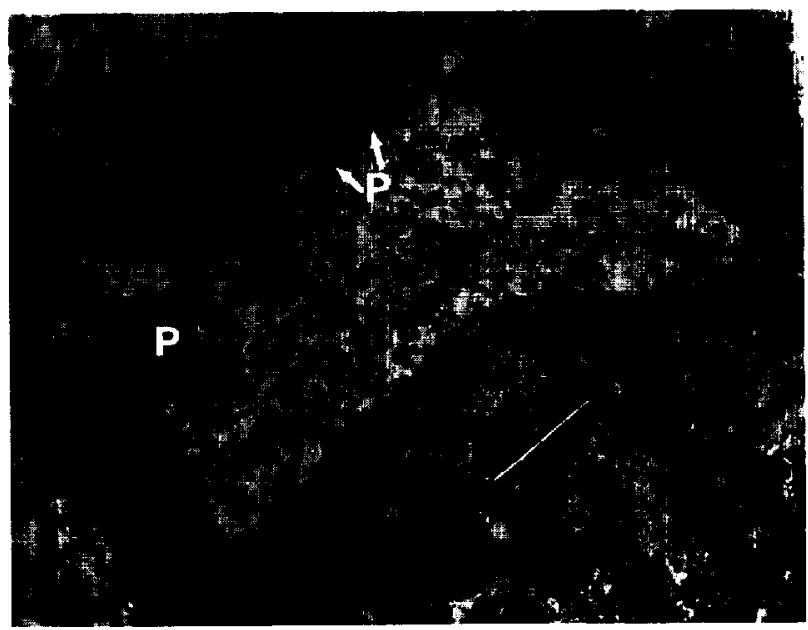

Fici. 9). Black Member glass ( sample 1 10-10) with one microprobe protile. The large fragment in the center of the figure contains some euhedral plagioclase (P). See also description of sample in text. Compare with Table 4. Length of photograph is $6.3 \mathrm{~mm}$. Plane polarized light. 

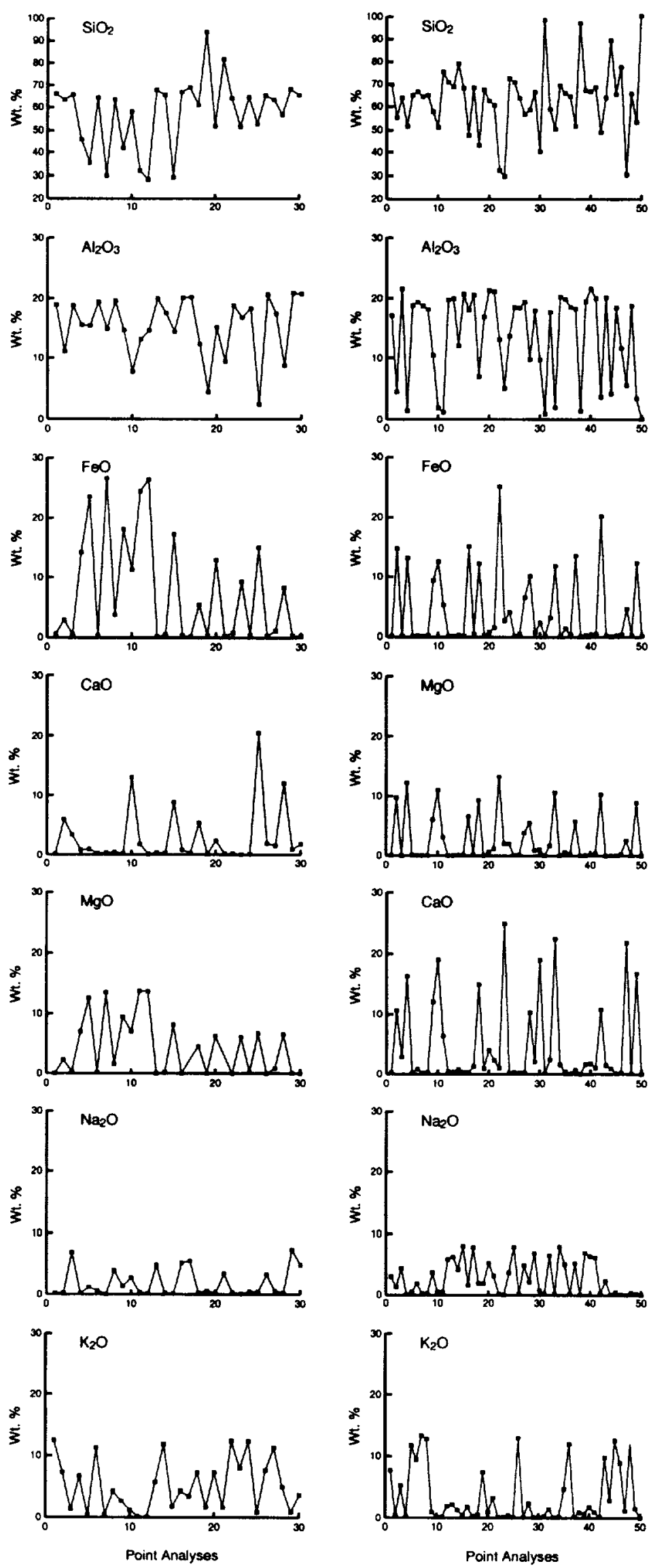

FIG. 10. Microprobe profiles across a glass fragment of the Gray Member (sample 34712). Compare with Fig. 2 and Tables 1 and 2. Right profile 2 is the longer profile. 

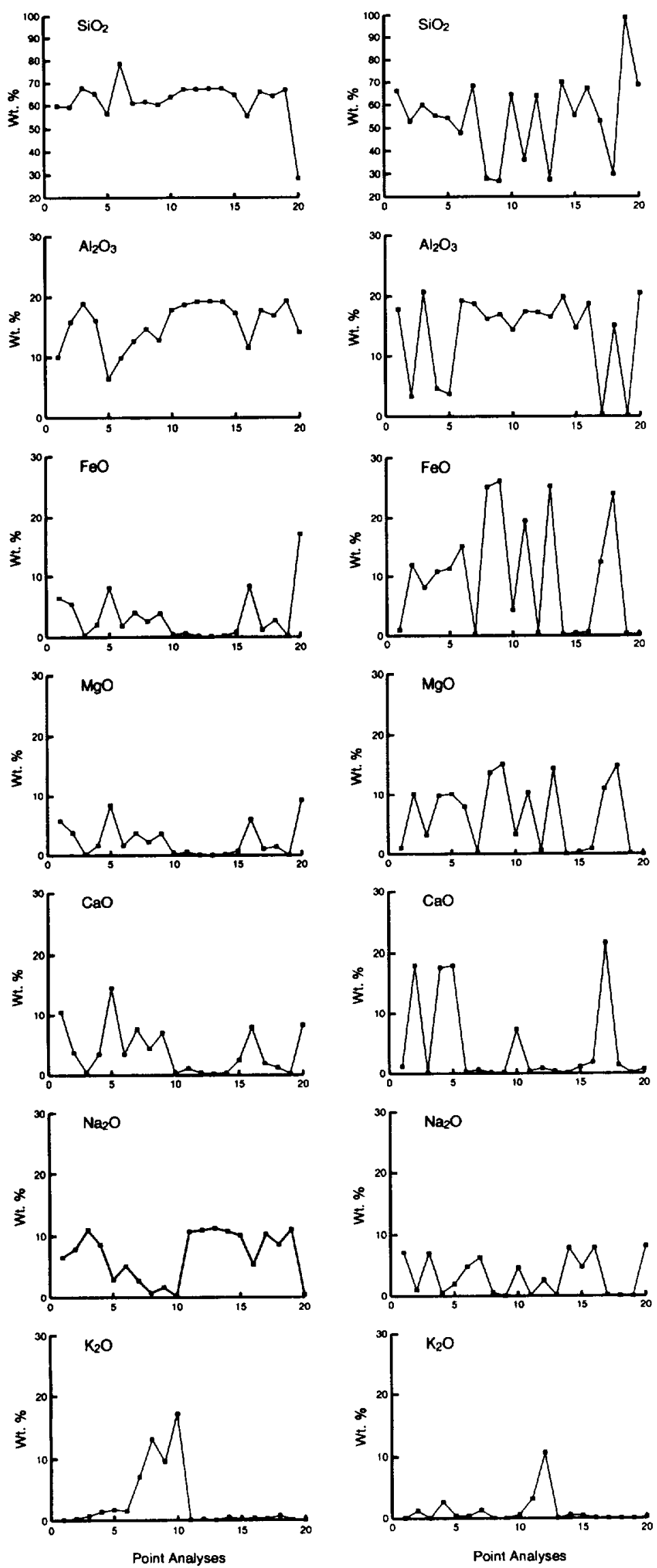

FIG 11. Microprobe profiles across a glass fragment of the Gray Member (sample 34717). Compare with Fig. 7 and Table 2. Right profile is the longer profile. 


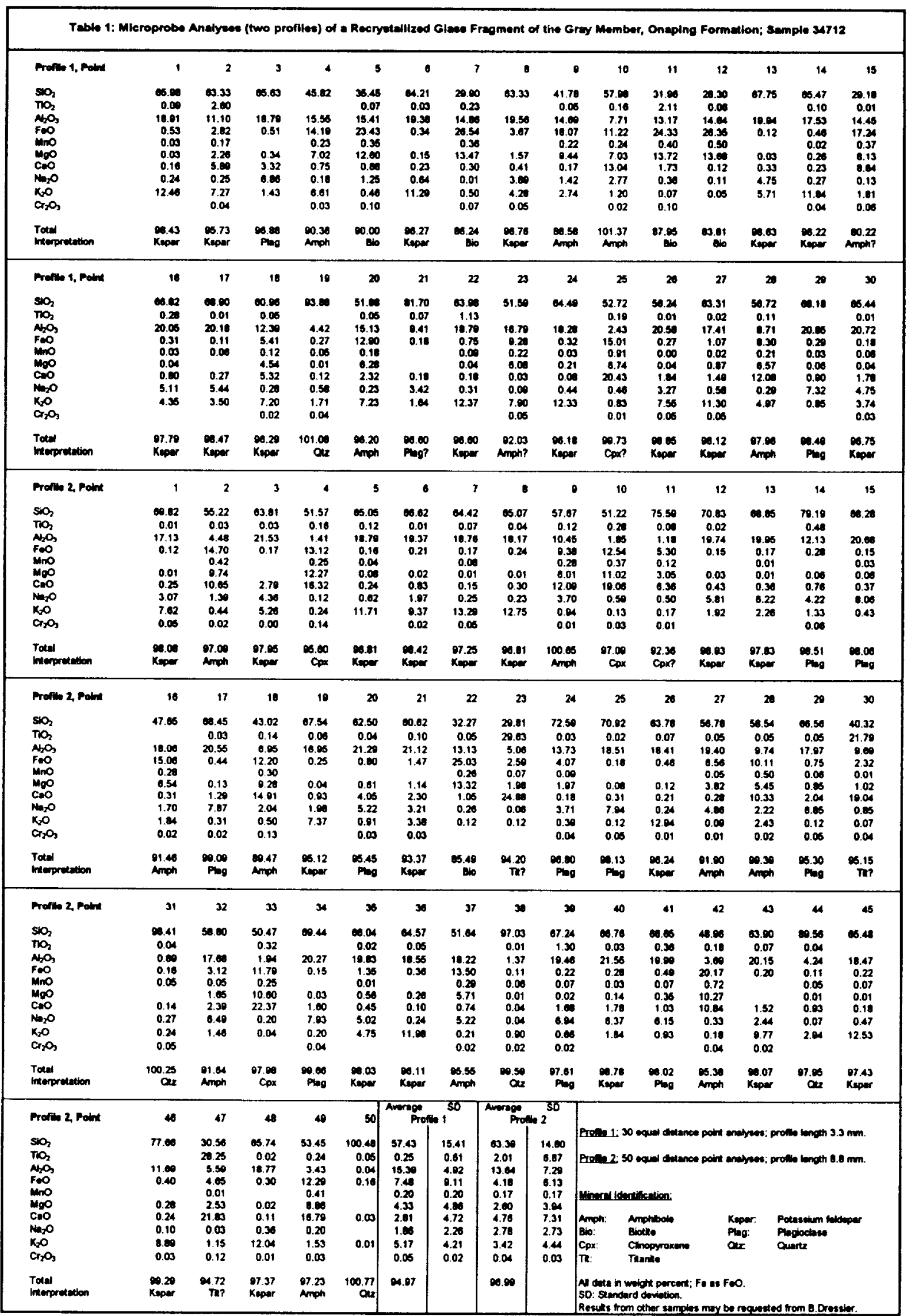




\begin{tabular}{|c|c|c|c|c|c|c|c|c|c|c|c|c|c|c|}
\hline \multirow{2}{*}{$\begin{array}{c}\text { Samplo } \\
n \\
\end{array}$} & \multicolumn{4}{|c|}{34712} & \multicolumn{2}{|c|}{$\begin{array}{l}34713 \\
\text { Profile } 1\end{array}$} & \multicolumn{4}{|c|}{34714} & \multicolumn{2}{|c|}{$\begin{array}{l}34715 \\
\text { Protile } 1\end{array}$} & \multicolumn{2}{|c|}{$\begin{array}{l}\text { 5P83-01 } \\
\text { Profite } 1\end{array}$} \\
\hline & \multicolumn{2}{|c|}{$\begin{array}{l}\text { Profile } 1 \\
\text { Average SO }\end{array}$} & \multicolumn{2}{|c|}{$\begin{array}{c}\text { Profile } 2 \\
\text { Average } \\
50 \\
\end{array}$} & $\begin{array}{r}\text { Pro } \\
\text { Average }\end{array}$ & - 1 so & \multicolumn{2}{|c|}{$\begin{array}{l}\text { Profile } 1 \\
\text { Average }_{30} \text { So }\end{array}$} & \multicolumn{2}{|c|}{$\begin{array}{c}\text { Profile }^{2} \\
\text { Avernge }{ }_{30}\end{array}$} & \multicolumn{2}{|c|}{${ }_{30}{ }_{30}$ SD } & \multicolumn{2}{|c|}{ Average ${ }_{\infty}$ SD } \\
\hline $\mathrm{SiO}_{2}$ & 57.73 & 15.21 & 63.30 & 14.80 & 64.40 & 13.90 & 03.78 & 0.35 & 64.60 & 12.61 & 02.30 & 16.31 & 72.83 & 14.48 \\
\hline $\mathrm{TO}_{2}$ & 0.34 & 0.88 & 201 & 6.87 & 0.40 & 1.84 & 0.03 & 0.03 & 0.80 & 3.64 & 1.00 & 4.88 & 0.01 & 0.02 \\
\hline $\mathrm{Al}_{2} \mathrm{O}_{3}$ & 15.30 & 4.83 & 13.64 & 7.20 & 15.27 & 0.00 & 13.84 & 5.23 & 13.01 & 7.00 & 10.75 & 6.75 & 13.03 & 8.24 \\
\hline $\mathrm{Cr}_{2} \mathrm{O}_{3}$ & 0.05 & 0.02 & 0.04 & 0.03 & 0.08 & 0.03 & 0.02 & 0.02 & 0.02 & 0.04 & 0.02 & 0.04 & 0.03 & 0.03 \\
\hline $\mathrm{F} \otimes \mathrm{O}$ & 7.48 & 8.00 & 4.18 & 0.13 & 3.65 & 5.43 & 3.00 & 3.24 & 4.17 & 5.06 & 6.02 & 7.36 & 2.24 & 4.57 \\
\hline $\mathrm{MnO}$ & 0.20 & 0.20 & 0.17 & 0.17 & 0.08 & 0.11 & 0.13 & 0.13 & 0.15 & 0.20 & 0.21 & 0.10 & 0.1 & 0.21 \\
\hline $\mathrm{MgO}$ & 4.33 & 477 & 2.00 & 3.04 & 1.08 & 2.10 & 2.80 & 3.15 & 3.57 & 4.80 & 4.32 & 4.07 & 1.78 & 3.57 \\
\hline $\mathrm{cmo}$ & 2.80 & 4.72 & 4.76 & 7.31 & 4.00 & 4.28 & 5.72 & 6.07 & 6.07 & 7.06 & 6.51 & 7.02 & 2.19 & 4.87 \\
\hline $\mathrm{Na} a_{2} \mathrm{O}$ & 1.80 & 2.23 & 2.78 & 2.73 & 3.31 & 2.74 & 7.50 & 3.10 & 4.58 & 3.37 & 3.91 & 3.37 & 0.43 & 4.46 \\
\hline $\begin{array}{l}\mathrm{K} 2 \mathrm{O} \\
\mathrm{P}_{2} \mathrm{O}_{3}\end{array}$ & 5.17 & 4.14 & 3.42 & 4.44 & 4.27 & 5.54 & 0.48 & 0.60 & 1.06 & 2.70 & 1.28 & 2.58 & 0.36 & 1.28 \\
\hline Total & 95.35 & & 00.80 & & 97.00 & & 97.54 & & 88.22 & & 97.22 & & $\infty . \infty$ & \\
\hline \multirow[t]{2}{*}{ Sample } & \multirow{2}{*}{\multicolumn{2}{|c|}{ Profile 1}} & \multicolumn{2}{|c|}{$16 \quad$ Profile 2} & \multirow{2}{*}{\multicolumn{2}{|c|}{ Profile 1}} & \multicolumn{2}{|c|}{ Profile 2} & \multicolumn{2}{|c|}{$\begin{array}{l}\text { 93-02 Aii } \\
\text { Randorn }\end{array}$} & \multicolumn{2}{|c|}{$\begin{array}{c}03-03 \\
\text { Random }\end{array}$} & \multicolumn{2}{|c|}{$\begin{array}{l}\text { 430-F } \\
\text { Rendom }\end{array}$} \\
\hline & & & Average & So & & & Average & so & $\begin{array}{r}\text { Average } \\
\quad 8 \\
\end{array}$ & & $\begin{array}{r}\text { Average } \\
10 \\
\end{array}$ & SD & $\begin{array}{r}\text { Averege } \\
50 \\
\end{array}$ & So \\
\hline $\mathrm{SiO}_{2}$ & 03.39 & 13.44 & 64.07 & 12.83 & 02.40 & 9.24 & 54.68 & 17.80 & 59.73 & 11.37 & 58.14 & 9.23 & 50.87 & 11.10 \\
\hline $\mathrm{TrO}_{2}$ & 0.70 & 2.70 & 0.10 & 0.74 & 0.40 & 1.00 & 0.05 & 0.05 & 2.48 & 6.15 & 2.15 & 4.83 & 0.91 & 2.72 \\
\hline $\mathrm{A}_{2} \mathrm{O}_{3}$ & 14.30 & 0.50 & 14.00 & 7.04 & 15.42 & 3.72 & 13.78 & 0.84 & 12.40 & 4.20 & 13.40 & 3.65 & 12.80 & 4.30 \\
\hline $\mathrm{Cr}_{2} \mathrm{O}_{3}$ & 0.05 & 0.08 & 0.02 & 0.03 & 0.03 & 0.03 & 0.06 & 0.05 & 0.03 & 0.03 & 0.04 & 0.03 & 0.02 & 0.02 \\
\hline F⿻o & 4.22 & 5.07 & 4.50 & 8.46 & 3.34 & 4.10 & 9.80 & 9.50 & 4.78 & 3.17 & 5.34 & 3.11 & 5.92 & 0.06 \\
\hline MnO & 0.15 & 0.20 & 0.18 & 0.25 & 0.13 & 0.12 & 0.28 & 0.24 & 0.17 & 0.00 & 0.17 & 0.08 & 0.11 & 0.00 \\
\hline $\mathrm{MgO}$ & 3.28 & 4.20 & 3.43 & 4.74 & 2.50 & 2.77 & 6.35 & 5.68 & 3.81 & 2.14 & $\begin{array}{l}4.33 \\
0.48\end{array}$ & $\begin{array}{l}2.22 \\
5.18\end{array}$ & $\begin{array}{l}3.12 \\
3.78\end{array}$ & $\begin{array}{l}2.30 \\
300\end{array}$ \\
\hline $\mathrm{Cm}$ & 4.74 & 5.80 & 4.72 & 7.20 & 3.00 & 3.08 & 4.50 & 7.31 & $\begin{array}{l}7.48 \\
803\end{array}$ & $\begin{array}{l}5.58 \\
281\end{array}$ & $\begin{array}{l}6.48 \\
4.82\end{array}$ & $\begin{array}{l}5.18 \\
2.95\end{array}$ & $\begin{array}{l}3.78 \\
0.79\end{array}$ & $\begin{array}{l}3.60 \\
1.06\end{array}$ \\
\hline $\mathrm{Na}_{2} \mathrm{O}$ & 5.14 & 3.20 & 5.00 & 3.70 & 6.77 & 3.98 & 3.28 & 3.08 & 6.03 & 2.81 & $\begin{array}{l}4.82 \\
3.06\end{array}$ & $\begin{array}{l}2.00 \\
3.97\end{array}$ & 0.42 & $\begin{array}{l}1.00 \\
4.06\end{array}$ \\
\hline $\mathrm{K}_{2} \mathrm{O}$ & 0.83 & 2.24 & 1.00 & 2.20 & 2.72 & 4.80 & 1.00 & 2.35 & 1.01 & $\begin{array}{l}1.32 \\
0.14\end{array}$ & $\begin{array}{l}3.86 \\
0.08\end{array}$ & 0.00 & 0.03 & 0.05 \\
\hline $\mathrm{P}_{2} \mathrm{O}_{5}$ & & & & & & & & & 0.00 & 0.14 & & & & \\
\hline Total & 98.00 & & 97.12 & & 07.85 & & 93.00 & & 88.01 & & $\infty .00$ & & $\infty .77$ & \\
\hline
\end{tabular}

weight percent values different from the values obtained from the other profile across the same glass fragment. The $\mathrm{SiO}_{2}$ numbers, for example, are 57.73 and $63.39 \mathrm{wt} \%$, respectively. The two profiles in the one analysed fragment of sample 34716 , however, are remarkably similar in bulk composition. In sample 34714 , we analysed two fragments having similar bulk chemical compositions.

Table 3, listing whole rock data of Gray Member fluidal glasses (Muir and Peredery, 1984), shows a wide range of chemical compositions. For example, $\mathrm{SiO}_{2}$ ranges from 59.9 to 75.1 wt $\%$ and $\mathrm{Fe}_{2} \mathrm{O}_{3}$ from about 1 to about $9 \mathrm{wt} \%$. These whole-rock chemical data substantiate our microprobe data. Table 4 gives microprobe and whole rock analyses of glass fragments of the Green and Black members of the Onaping Formation. Both members are characterized by the high abundance of chloritized fragments, which are products of postdeposition alteration of glass of probably originally basic composition. Non-chloritized glass fragments are similar in chemical composition to those in the gray member, and exhibit a wide range of bulk compositions. For example, $\mathrm{SiO}_{2}$ ranges from about 59 to about $61 \mathrm{wt} \%$, and $\mathrm{Al}_{2} \mathrm{O}_{3}$ ranges from approximately 5 to about $15 \mathrm{wt} \%$.

\section{CHEMISTRY OF THE GLASSES, MELT BODIES, AND MELT BRECCIAS OF THE ONAPING FORMATION AND THE SUDBURY IGNEOUS COMPLEX: A COMPARISON}

Both fluidal and nonfluidal glass fragments in the suevitic breccias of the Onaping Formation, as shown above, have a considerable range of bulk compositions. This is in contrast to results from the Ries impact crater in Germany (Hörz, 1965; Engelhardt, 1972) where glass fragments in the suevite are characterized by a relatively homogeneous chemical composition reflecting a homogeneous target rock in the zone of impact melting. However, impact glasses are not homogeneous in all terrestrial impact structures. This is shown by our results and, for example, also by data from the Zhamanshin impact structure in the Aral region of Kazakhstan, where impact glasses were subdivided into four groups based on their average $\mathrm{SiO}_{2}$ content of about 55, 65, 73, and $93 \mathrm{wt} \%$. These impact glasses inherited the chemistry of target rocks and are not evenly distributed in and around the crater (Feldman and Sazonova, 1993). In the following we compare the bulk chemical compositions of glasses and impact melts of the Onaping Formation with the bulk compositions of the SIC. The rationale for this comparison and some background information are presented first. 
Table 3: Fluidal Glasses in Gray Member of the Onaping Formation - Whole Rock Analyses

\begin{tabular}{|c|c|c|c|c|c|c|c|c|c|c|c|c|c|}
\hline & 1 & 2 & 3 & 4 & 5 & 6 & 7 & 8 & 9 & 10 & 11 & Average & so \\
\hline $\mathrm{SlO}_{2}$ & 65.90 & 65.20 & 59.90 & 61.50 & 69.40 & 62.40 & 75.10 & 61.80 & 62.30 & 65.10 & 62.40 & 64.64 & 4.36 \\
\hline $\mathrm{THO}_{2}$ & 0.95 & 0.76 & 0.58 & 0.71 & 0.78 & 1.01 & 0.58 & 0.93 & 0.85 & 0.78 & 0.74 & 0.79 & 0.14 \\
\hline $\mathrm{Al}_{2} \mathrm{O}_{3}$ & 11.00 & 12.60 & 14.00 & 15.80 & 12.50 & 13.50 & 9.87 & 12.60 & 13.30 & 12.30 & 11.40 & 12.62 & 1.58 \\
\hline $\mathrm{Fe}_{2} \mathrm{O}_{3}$ & 5.63 & 5.13 & 0.91 & 1.02 & 4.48 & 4.84 & 4.12 & 8.12 & 6.85 & 7.89 & 0.25 & 6.45 & 1.72 \\
\hline $\mathrm{FQO}$ & & & 6.40 & 4.94 & & & & & & & & & \\
\hline Mno & 0.23 & 0.13 & 0.13 & 0.14 & 0.06 & 0.09 & 0.06 & 0.12 & 0.14 & 0.14 & 0.13 & 0.12 & 0.05 \\
\hline MgO & 4.28 & 3.37 & 4.27 & 4.03 & 3.10 & 5.12 & 2.20 & 4.76 & 4.68 & 5.04 & 4.95 & 4.16 & 1.15 \\
\hline $\mathrm{CoO}$ & 4.51 & 3.76 & 3.96 & 3.65 & 1.24 & 4.06 & 0.70 & 3.20 & 2.72 & 1.88 & 2.78 & 3.01 & 1.15 \\
\hline $\mathrm{Na}_{2} \mathrm{O}$ & 4.28 & 4.68 & 4.27 & 5.10 & 4.53 & 6.88 & 1.06 & 3.33 & 4.75 & 4.31 & 4.24 & 4.31 & 1.38 \\
\hline $\mathrm{K}_{2} \mathrm{O}$ & 1.90 & 3.06 & 2.25 & 1.81 & 0.91 & 0.22 & 4.54 & 3.10 & 2.11 & 0.29 & 0.85 & 1.91 & 1.32 \\
\hline $\mathrm{P}_{2} \mathrm{O}_{6}$ & 0.04 & 0.05 & 0.12 & 0.12 & 0.01 & 0.05 & 0.00 & 0.04 & 0.05 & 0.04 & 0.04 & 0.05 & 0.04 \\
\hline $\mathrm{CO}_{2}$ & 0.36 & 0.14 & 0.14 & 0.00 & 0.29 & 0.12 & 0.20 & 0.11 & 0.11 & 0.09 & 0.10 & 0.16 & 0.09 \\
\hline s & 0.23 & 0.19 & 0.01 & 0.03 & 0.01 & 0.01 & 0.02 & 0.03 & 0.03 & 0.11 & 0.02 & 0.06 & 0.08 \\
\hline $\mathrm{H}_{2} \mathrm{O}^{+}$ & & & 1.49 & 0.69 & & & & & & & & & \\
\hline $\mathrm{H}_{2} \mathrm{O}^{\circ}$ & & & 0.38 & 0.40 & & & & & & & & & \\
\hline $\begin{array}{l}\text { Tolal } \\
\text { LOI }\end{array}$ & $\begin{array}{c}99.31 \\
0.90\end{array}$ & $\begin{array}{l}99.07 \\
1.00\end{array}$ & $\begin{array}{c}98.82 \\
1.10\end{array}$ & $\begin{array}{c}100.03 \\
0.80\end{array}$ & $\begin{array}{l}98.01 \\
1.50\end{array}$ & $\begin{array}{l}28.30 \\
0.80\end{array}$ & $\begin{array}{l}98.45 \\
1.60\end{array}$ & $\begin{array}{c}98.14 \\
1.80\end{array}$ & $\begin{array}{l}97.99 \\
1.90\end{array}$ & $\begin{array}{l}97.97 \\
2.30\end{array}$ & $\begin{array}{l}96.90 \\
2.10\end{array}$ & $\begin{array}{l}98.3 \\
1.4\end{array}$ & \\
\hline
\end{tabular}

Within an impact scenario, the SIC has recently been interpreted as either an impact melt body (Faggart et al., 1985; Grieve et al., 1991; Grieve, 1994) or as a combination of an impact melt and an intrusive body (Dence, 1972; Shanks et al., 1990; Chai and Eckstrand, 1993, 1994; Johns and Dressler, 1995). Faggart et al. (1985) provided isotopic evidence for crustal derivation of the SIC. They reported Sm$\mathrm{Nd}$ isotopic results for the norite and quartz gabbro of the SIC (average $\varepsilon_{N d}=-7.5$ ) and interpreted them to mean that the magma was derived entirely from melting of Precambrian target rocks. Deutsch (1994) reported isotopic data of

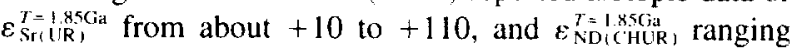
from -4 to -12 , and $\mathrm{Nd}$ model ages relative to a depleted mantle between 3.2 and $2.7 \mathrm{Ga}$ for rocks of the SIC and impact mell fragments of the Gray and Green members of the Onaping Formation. All this, according to Deutsch (1994) supports whole rock melting of crustal rocks. Grieve et al. (1991) published a mixing model for the SIC combining various Archean and Proterozoic target rocks and compared a theoretical melt composition with the bulk composition of the SIC. Shanks et al. (1990) and Johns and Dressler (1995) pointed to field and structural evidence that they believed not to be consistent with the interpretation of all of the SIC as an impact melt sheet. They noticed that the Sublayer contains inclusions of norite, in places intrudes the norite, and has inclusions aligned with their long dimension parallel to the contact with the norite. All this is good field evidence for a post-norite intrusion age of the sublayer. We also wish

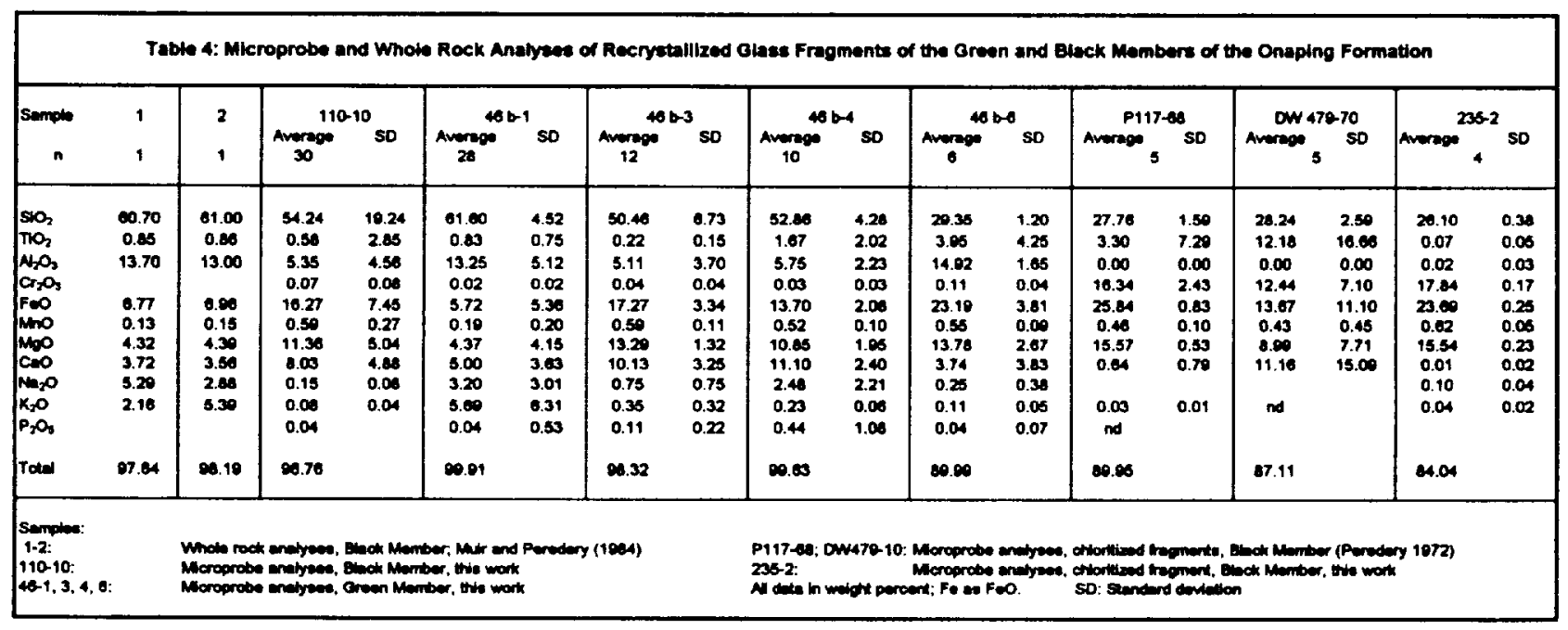


to point to the fact that the SIC is apparently not ponded, as shown by the seismic profiles of $W_{u}$ et al. (1994). Large melt sheets filling impact craters, however, are. Lightfoot (Ontario Geological Survey, pers. commun.) obtained U-Pb age dates of about $1.85 \mathrm{Ga}$ on baddeleyites of mafic/ultramafic inclusions in the Sublayer, suggesting differentiation of mafic/ultramafic, unexposed SIC units that were subsequently incorporated as inclusions in the Sublayer. In the northeastern and southeastern parts of the SIC, the granophyre exhibits strong solid-state deformation, whereas norite and quartz gabbro are virtually undeformed. All this suggests that the granophyre is the oldest SIC phase and might represent an impact melt sheet. Norite and Sublayer are younger. This interpretation is supported by geochemical investigations of Chai and Eckstrand (1993, 1994) who believe that the SIC represents two independent magmas. The norite was derived from strongly contaminated mantle magma, the granophyre from impact melting of Archean and Huronian rocks. The two major rock types of the SIC, according to these authors, have distinct chemical compositions and cannot be related by fractional crystallization from a single magma. For example, they point to a negative correlation between ${ }^{87} \mathrm{Rb} /{ }^{86} \mathrm{Sr}$ and initial ${ }^{87} \mathrm{Sr} /{ }^{46} \mathrm{Sr}$ ratios of granophyre and norite of the SIC. Furthermore, they believe that a sharp change in chemical compositions in the transition from norite to granophyre is not supportive of a single magma origin of the SIC. $\mathrm{SiO}_{2}$ and $\mathrm{K}_{2} \mathrm{O}$ increase dramatically, while $\mathrm{Al}_{2} \mathrm{O}_{3}$, $\mathrm{MgO}$, and $\mathrm{CaO}$ decrease abruptly. REE contents also change abruptly across this transition. The quartz gabbro is believed to represent mixing of the contaminated, mantle-derived magma and the granophyre impact melt.

If the various glass fragments, the melt bodies, and the melt matrix of the North Range Basal Member of the Onaping Formation (Peredery, 1972a,b; Muir and Peredery, 1984) were derived by shock melting of target rocks, they should, individually or mixed, represent an average chemical composition of the bulk SIC - if Faggart et al. (1985), Grieve et al. (1991), Grieve (1994), and Deutsch (1994) are correct, - or of the granophyre --if the interpretation by Shanks et al. (1990), Chai and Eckstrand (1993, 1994), and Johns and Dressler ( 1995 ) is correct. To test these hypotheses, we have compiled a large number of geochemical data on the various glasses and melts of the Onaping Formation (mainly after Muir and Peredery, 1984). These data are compared with our analytical results and with the three main components and the bulk composition of the SIC in Fig. 12a-d. (Here we show only the plots for a limited number of chemical components. Other, not plotted, components support the interpretations derived from the limited number of plots shown.) The glasses and the various melts are represented by wide compositional ranges. Black Member glasses appear to occupy two small individual fields, unless this is a result of th: small number of black member glass analyses available. The Melt Bodies range in chemical composition from dacite to basalt (Muir and Peredery, 1984). The granophyre of the SIC occupies fields in Fig. 12 that overlap with the compositional ranges of various glasses and melts of the Onaping Formation. The bulk composition of the SIC plots close to the average granophyre composition reflecting the relatively large granophyre volume $(76 \%)$ in contrast with the volume of the other two main components of the SIC ( $13 \%$ norite and $11 \%$ quartz gabbro). These percentages are based on the areal extend of the three main units in the North Range from where our data on the SIC were obtained (courtesy of P. Lightfoot, Ontario Geological Survey). The rocks there are undeformed and little altered.

\section{DISCUSSION}

Recrystallized glasses of the Onaping Formation show a considerable range of bulk geochemical compositions and most of our microprobe profiles across single recrystallized glass fragments show that the glasses, internally, are very heterogeneous too. We have also shown that bulk compositions obtained from more than one profile across a glass fragment are either more or less the same or distinctly different from each other. Furthermore, in a few samples we have analysed more than one glass fragment per polished section. Our results indicate that glasses of essentially the same bulk composition or fragments of different compositions occur close together. The limited number of rock thin sections studied under the microscope and the relatively small number of samples analysed by microprobe do not represent a meaningful number to allow us to statistically establish the abundances of diaplectic versus liquid-state impact glasses. Liquid-state glasses are recognized by their fluidal texture. Some diaplectic glasses can be identified by relict rock textures. For example. we have recognized glasses, and analysed one sample of them (see Fig. 8 of sample 5p83-01), with petrographic features reminiscent of unaltered, diaplectic glasses derived from metasedimentary rocks of the Proterozoic Huronian Supergroup. Similar glasses are commonly found in the suevite of the 37 Ma old Wanapitei impact structure (Dressler et al., 1996) just east of the SIC. The target rocks of both the Sudbury and Wanapitei structures in part were metasedimentary rocks of the Huronian Supergroup.

All these observations are different from what we know about volcanic regimes, where, in general, felsic glasses occur in felsic volcanic assemblages and mafic glasses in mafic volcanic assemblages and are not intermixed. However, Sigurdson and Sparks (1981) described a volcanic deposit containing rhyolitic to basaltic fragments. The glass fragments of the Onaping Formation are intermixed with a wide range of mineral and country rock fragments, many of which exhibit microscopic shock metamorphic features such as planar deformation features in quartz and feldspar. Several of the fragments annalysed by us, and many others studied with the petrographic microscope, contain various types of rock inclusions suggestive of a melting process involving more than one target rock type. All this is distinctly different from volcanic breccia deposits and is convincing evidence for an impact origin of the glasses and the breccia deposits of the Onaping Formation.

The various Melt Bodies and the melt matrix of the Basal Member of the Onaping Formation are chemically heterogeneous (Peredery, 1972a; Muir and Peredery, 1984; Brockmeyer, 1990). A comparison of the major element bulk compositions of glass fragments, of samples of Melt Bodies, and of the melt matrix of the Basal Member of the Onaping Formation with the average composition of the SIC shows 

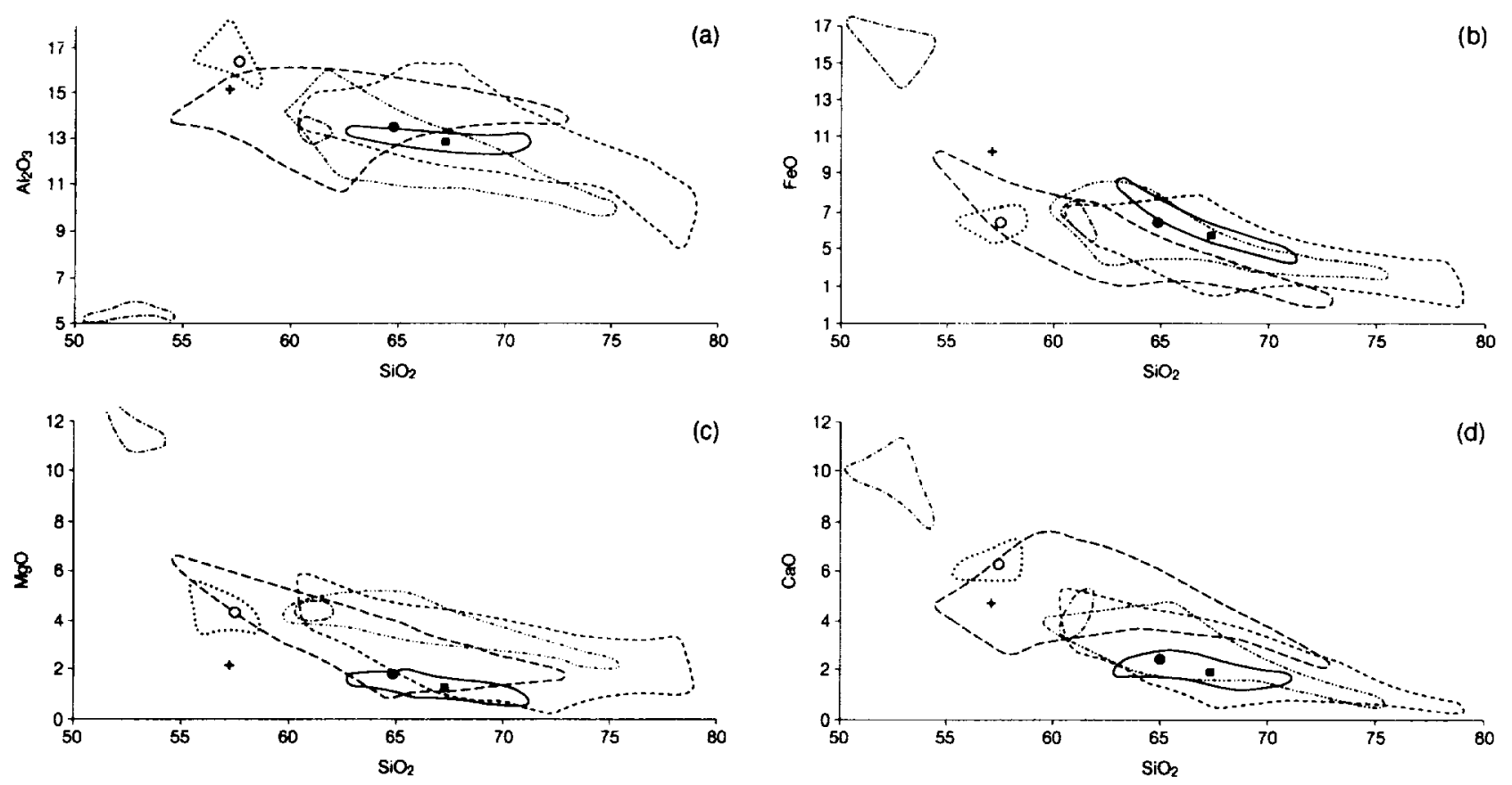

\section{Onaping Formation}

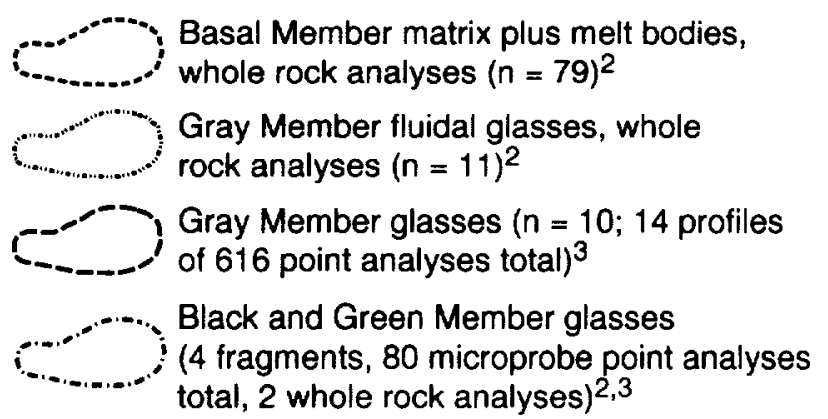

\section{Sudbury Igneous Complex ${ }^{1}$}

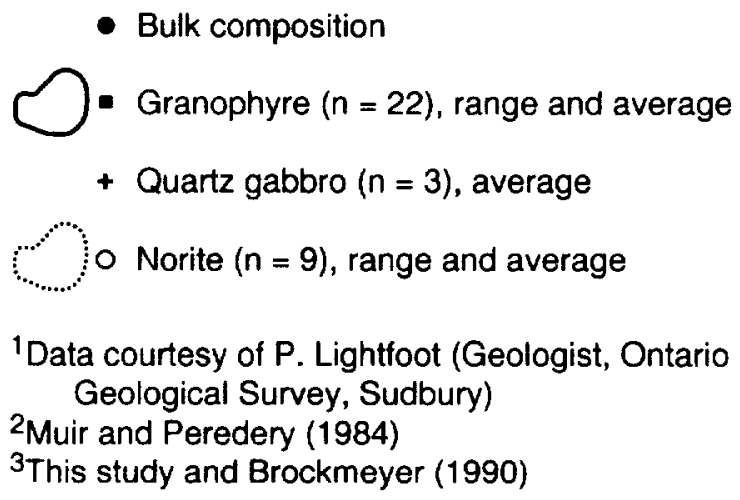

FIG. 12. Comparison of chemical compositions of various components of the Onaping Formation and of the Sudbury Igneous Complex.

that none of all these various melts, all of which were produced during the impact process, was mixed to form a homogeneous melt before ejection and incorporation into the breccias of the Onaping Formation. It also leads to the conclusion that either the granophyre of the SIC alone or the whole mass of the differentiated SIC may be the Sudbury impact melt. If the granophyre of the SIC is in fact the Sudbury impact melt, the other phases of the SIC resulted from impact triggered magmatism. Basal Member matrix and Melt Bodies (Peredery, 1972a) are, in fact, similar in chemical composition to the granophyre (Table 5) possibly suggesting that they are genetically related. The geochemical similarity of the Melt Bodies (Peredery, 1972a,b) and the granophyre of the SIC had been recognized in the past by Muir (1984); however, he advocated an endogenic origin for the Onaping Formation (Muir, in Muir and Peredery, 1984).
Based on our chemical results alone, the entire SIC or the granophyre alone represent the Sudbury impact melt. Major element geochemistry alone does not provide a solution for this problem; however, we believe that we can differentiate between these two possibilities by taking a number of distinctive field observations in consideration. One of us, B. Dressler, has observed three intrusive phases of Sublayer where, of which at least two are post-norite in age as they intrude the norite as dikes and contain inclusions of norite (Dressler, 1980, 1981, 1982). As stated above, contact relationships of the Sublayer with the norite at the base of the SIC also suggest that the Sublayer intruded after the emplacement of the norite (Dressler, 1982; Johns and Dressler, 1995). The rocks of the Onaping Formation and the granophyre in the southeastern and northeastern corners of the SIC, as well as the footwall rocks beneath the SIC, are 


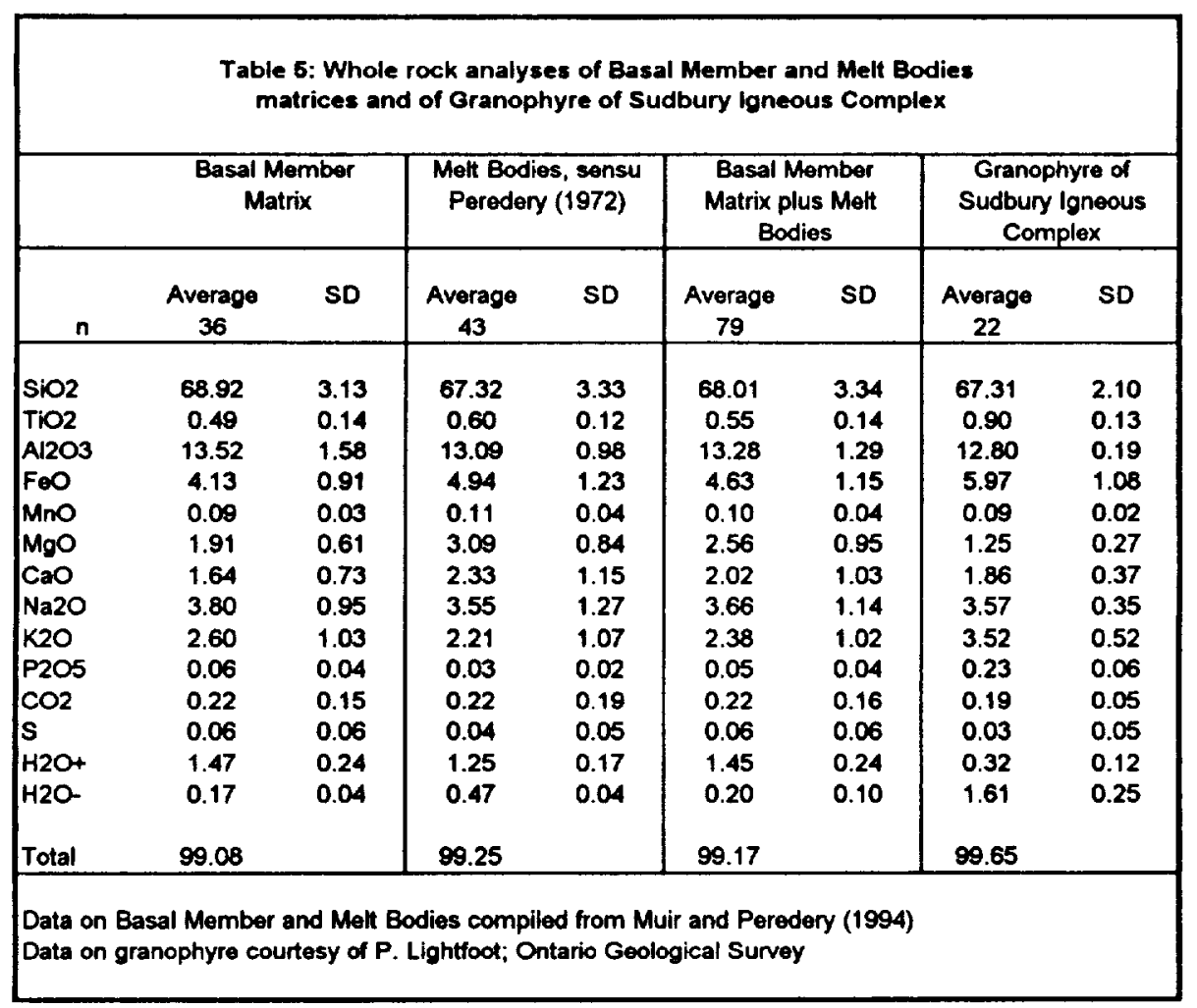

strongly deformed where two regional ductile deformation zones cut across the SIC. Norite and quartz gabbro at these locations, however, are not deformed (Dressler, 1987: Shanks et al., 1990; Shanks and Schwerdtner, 1991; Cowan and Schwerdtner, 1994; Johns and Dressler, 1995). This is further evidence that not all phases of the SIC are exactly of the same crystallization age. These field observations, in our opinion, suggest that the entire SIC is not a rapidly emplaced, differentiated impact melt sheet. This is supported by the chemical investigations of Chai and Eckstrand (1993, $1994)$ who maintain that the SIC represents two distinct magmas, one contaminated and mantle-derived (norite), the other an impact melt (granophyre). Isotopic investigations, however, provide evidence that the entire SIC, not only the granophyre and including the Sublayer and its ores, represents an impact melt (e.g., Faggart et al., 1985; Deutsch, $1994)$.

Nonetheless, we infer that the granophyre of the SIC is in fact the impact melt sensu stricto; norite and the phases of the sublayer are the result of impact-induced deep crustal melting. The induced melting occurred in response to shock heating, brecciation, and post-impact hydrostatic pressure release. The deep crustal and contaminated melts possibly intruded beneath a more or less solidified, in part deformed granophyre mass. Evidence obtained from the study of large lunar multi-ring impact basins suggest that impact-induced upwelling of mantle beneath a large impact basin may occur and result in endogenic, magmatic activity, even at a considerable time after the impact (Solomon et al., 1982). The Sudbury structure represents a partially eroded, terrestrial equivalent of a large lunar multi-ring impact basin (Stöfler et al., 1989). The deep crustal melting proposed here may have tapped a reservoir such as that of the $2.2 \mathrm{Ga}$ old Nipissing intrusive rocks. Constrained by radiometric ages, we have to assume that this "magmatic" event occurred within 1-2 Ma of the impact event, because all phases of the SIC have very similar ages of about $1.85 \mathrm{Ga} \pm 1$ to $3 \mathrm{Ma}$ (Krogh et al., 1984). All, that is at least two, Sublayer phases intruded after the emplacement of the norite (Dressler, 1982; Dressler in Naldrett et al., 1984). Mafic and ultramafic inclusions in the Sublayer are also about 1.85 Ga old ( $P$. Lightfoot, Ontario Geological Survey, pers. commun. to B.O.D., 1995), which provides further evidence for multistage magmatic activities within a relatively short period of time. These fragments probably represent lower, not exposed, units of the SIC and were brought to their present position by the sublayer magma. Field observations, theoretical considerations related to melt production during planetary impact processes (Dence et al., 1977; Lange and Ahrens, 1979; Melosh. 1989), and age determinations, therefore, suggest a relatively rapid succession of impact melting (glasses and impact breccias of the Onaping Formation; granophyre), and impact-triggered magmatic activity and differentiation ( norite), followed by intrusion of post-norite sublayer phases that contain inclusions derived from lower and unexposed phases of the SIC.

The considerable compositional variety of solid-state and/ or liquid-state glasses of the Onaping Formation is suggestive of shock vitrification of a large variety of rocks. Mixing of melts never was complete prior to the termination of the 
excavation and ejection phase of the Sudbury impact process. Melts ejected from impact structures, therefore, may be different in composition from the commonly very homogeneous impact melt sheets remaining in the crater cavity. Our interpretation is supported by observations from the $100 \mathrm{~km}$ diameter Popigai impact structure in Russia, where ejected melt fragments are, in part, chemically different from the composition of the melt sheet within the crater (Masaitis et al., 1976). It is also supported by-admittedly less constrained-observations on Apollo 16 impict melt ejecta where the most abundant textural group of melt fragments is compositionally diverse, but interpreted to be all derived from the $1320 \mathrm{~km}$ diameter Nectaris nulti-ring impact basin (Spudis, 1984). The ejected melt fragments may be different in composition from a continuous impact melt body within the impact basin (Spudis. 1993).

\section{CONCLUSION}

We have presented new microprobe analytical data on recrystallized, solid-state and liquid-state impact glasses of the suevitic breccias of the Onaping Formation, Sudbury impact structure. Ontario, Canada. We have compared our results with published whole-rock analyses, including those of recrystatlized glasses, of the matrix of an impact melt breccia and impact melt bodies (all of the Onaping Formation ), and of the bulk compositions of the Sudbury Igneous Complex and its components. Our microprobe work supports the shock origin of the glasses of the Onaping Formation. Based on our chemical comparison alone, the entire igneous complex or the granophyre alone represent the Sudbury impact melt sheet. Geological field evidence, however, leads us to accept the second interpretation, in which the norite and the Sublayer of the igneous complex represent contaminated, endogenic, magmas, the granophyre a basin-filling impact melt.

We believe that a more comprehensive microprobe study of the components of the Onaping Formation may provide evidence for an even wider range of glass compositions reflecting a wide range of target rock compositions. This would further support our interpretation for the various units of the Onaping Formation. Detailed field investigations, including a study of the contact relationships of the various phases of the Sudbury Igneous Complex and a re-evaluation of structural evidence, of published whole rock chemistry, and trace element and isotope geochemical data, are needed to establish a Sudbury impact model encompissing all laboratory and field observations.

Acknowledgments-The authors are grateful for many stimulating discussions with our colleagues at the Onturio Geological Survey. Sudbury. Ontario, Inco Ltd.. Sudbury, Ontario, the Institut für Planetologie. University of Münster. Germany, and the L unar and Planetary Institute, Houston, Texas, USA. We thank P. Lightfoot of the Ontario Geological Survey for new and unpublished geochemical and geochronological information on the Sudbury Igneous Complex. The publication benefited greatly from the comments of $W$. V. Peredery. W. U. Reimold, and G. Ryder. This is Lunar and Planetary Institute contribution 882 .

Editorial handling: C. Koeberl

\section{REFERENCES}

Arnd J.. Hummel W.. and Gonzales-Cabeza I. (1982) Diaplectic labradorite glass from the Manicouagan impact crater-.-Physical properties, crystallization, structural and genetic implications. Phys. Chem. Minerals 8, 230-239.

Avermann M.-E. (1992) Die Genese der allochthonen, polymikten Breccien der Onaping-Formation, Sudbury-Struktur, Ontario, Kanada. Ph.D. thesis, University of Münster.

Avermann M.-E. and Brockmeyer P. (1992) The Onaping Formation of the Sudbury Structure (Canada): An example of allochthonous impact breccias. Tectomophysic's 216, 227-234.

Becker L., Bada J. L., Winans R. E., Hunt J. E., Bunch T. E., and French B. M. (1994) Fullerenes in the 1.85-billion-year-old Sudbury impaci-structure. Science 265, 642-645.

Brockmeyer P. (1990) Petrographie, Geochemie und Isotopenuntersuchungen an der Onaping-Formation im Nordteil der SudburyStruktur (Ontario, Kanada) und ein Modell zur Genese der Struktur. Ph.D, thesis, University of Münster.

Burrows A. G. and Rickaby H. C. (1930) Sudbury basin area. Ontario Department of Mines, Annual Report for 1929, 38, part 3. $1-55$.

Card K. D. and Hutchinson R. W. (1972) The Sudbury Structure: Its regional geological setting. In New Developments in Sudbury Geology (ed. J. V. Guy-Bray); Geol. Assoc. Canada. Spec. Paper 10. $67-78$.

Chai G. and Eckstrand R. O. (1993) Origin of the Sudbury Igneous Complex, Ontario - differentiate of two separate magmas. Current Research, Part E; Geol. Survey of Canada, Paper 9.3-JE. $219-230$.

Chai G. and Eckstrand R. (1994) Rare-earth element characteristics and origin of the Sudbury Igneous Complex. Ontario, Canada. Chem. Geol. 113, 221-244.

Corfu F. and Andrews A. J. ( 1986 ) A U-Pb age for mineralized Nipissing diabase. Gowganda, Ontario. Canadian J. Earth Sci. 23, $107-109$.

Cowan E. J. and Schwerdtner W. W. (1994) Fold origin of the Sudbury Basin. Ontario. In Proceedings of the Sudbury-Noril'sk Symposium (ed. P. C. Lightfoot and A. J. Naldrett): Ontario Geol. Survey, Spec Vol 5, 45-55.

DeCarli P. S. and Milton D. J. (1965) Stishovite, synthesis by shock wave. Science $168,127-130$

Dence M. R. (1972) Meteorite impact craters and the structure of the Sudbury Basin. In New Developments in Sudhury Geology: (ed. J. V. Guy-Bray): Geol. Assoc. Canada, Spec. Paper 10. 718.

Dence M. R., Grieve R. A. F., and Robertson P. B. ( 1977) Terrestrial impact structures: Principal characteristics and energy considerations. In Impact and Explosion Cratering (ed. D. J. Roddy et al.), pp. 247-275. Pergamon Press.

Deutsch A. (1994) Isotope systematics support the impact origin of the Sudbury Structure (Ontario, Canada). In Large Meterrite Impacts and Planetary Evolution (ed. B. O. Dressler et al.); GSA Spec. Paper 293, 289-302.

Dietz R. A. (1964) Sudbury as an astrobleme. J. Geol. 72, 4124.34.

Dressler B. O. (1980) Footwall of the Sudbury irruptive, District of Sudbury. Onturio Geol. Survey, Misc ellaneons Paper 96, 83-86.

Dressler B. (0. (1981) Footwall of the Sudbury irruptive, District of Sudbury. Ontario Geol. Survey, Miscellaneous Paper 100, 84 87.

Dressler B. O. ( 1982 ) Footwall of the Sudbury irruptive, District of Sudbury, Ontario Geol. Survey, Miscellaneous Paper 106, 73 75.

Dressler B. O. (1984) The effects of the Sudbury event and the intrusion of the Sudbury Igneous Complex on the footwall rocks of the Sudbury Structure. In The Geslegy and Ore Deposits of the Sudbury Sirucrure' (ed. E. G. Pye et al.); Ontario Geol. Survey, Spec. Vol. 1, 97-136

Dressler B. O. 11987 ) Precambrian geology of Falconbridge Township. Ontario Cieol Suney, Map P. 3067.

Dressler B. O., Morrison G. G., Peredery W. V., and Rao B. V. (1987) The Sudbury Structure, Ontario, Canada-A review. In 
Research in Terrestrial Impact Structures (ed. J. Pohl), pp. 3968. Friedr. Vieweg \& Sohn.

Dressler B. O., Gupla V. K., and Muir T. L. (1991) The Sudbury Structure. In Geology of Ontario (ed. P. C. Thurston et al.); Ontario Geol. Survey, Spec: Vol. 4, Part 1, 593-626.

Dressler B. O., Crabtree D., and Schuraytz B. C. (1996) Incipient melt formation and devitrification of glasses at the Wanapitei impact structure, Ontario, Canada. Meteoritics and Planetary Science (submitted).

Engelhardt W. v. (1972) Shock produced glasses from the Ries crater. Comtrib. Mineral. Petrol. 36, 265-292.

Engelhardt W. v. ( 1990 ) Distribution, petrography and shock metamorphism of the ejecta of the Ries crater in Germany-A Review. Tectonophysics 171, 259-273.

Engelhardt W. V. and Bertsch W. (1969) Shock induced planar deformation structures in quartz from the Ries crater, Germany. Contrib. Mineral. Petrol. 20, 203-234.

Engelhardt W. v. and Graup G. (1977) Stoßwellenmetamorphose im Kristallin der Forschungsbohrung Nördlingen 1973. Geologica Bavarica 75, 255-27!.

Faggart B. E., Basu A. R., and Tatsumoto M. (1985) Origin of the Sudbury Structure by meteorite impact: Neodymium isotopic evidence. Science 230, 436-439.

Feldman V. I. and Sazonova L. V. (1993) Conditions of impact melt formation and solidification in the Zhamanshin astrobleme. Petrology 1, 523-538. (Translated by Interperiodica from Petrologiva $1,596-614$ ).

Floran R. J., Grieve R. A. F., Phinney W. C., Warner J. L., Simonds C. H., Blanchard D. P., and Dence M. R. (1978) Manicouagan impact melt, Quebec, 1, stratigraphy, petrology, and chemistry. J. Geophys. Res. 83, 2737-2759.

Frarey M. J., Loveridge W. D., and Sullivan R. W. (1982) A U-Pb zircon age for the Creighton granite, Ontario. In $R b-S r$ and $U-P b$ Isolopic Studies, Report 5, Current Research, Part C, Geol. Suney of Canada, Paper 81-1C, 129-132.

French B. M. (1966) Shock Metamorphism of natural materials. Sicience 153, 903-906.

French B. M. ( 1967 ) Sudbury Structure, Ontario: Some petrographic evidence for origin by meteorite impact. Science 156, 1094-1098.

French B. M. (1968) Sudbury Structure, Ontario: Some petrographic evidence for an origin by meteorite impact. In Shock Metamorphism of Natural Materials (ed. B. M. French and N. M. Short), pp. 383-412. Mono Book Corp.

French B. M. (1972) Shock metamorphic features in the Sudbury Structure, Ontario: A Review. In New Developments in Sudbury Geology (ed. J. V. Guy-Bray); Geol. Assoc. Canada, Spec. Paper 10. $19-28$.

French B. M. and Short N. M., eds. (1968) Shock Metamorphism of Natural Materials. Mono Book Corp.

Gibbins S. F. M. (1994) Geology, geochemistry, stratigraphy, and mechanism of emplacement of the Onaping Formation, Dowling area, Sudbury Structure, Ontario, Canada. M.Sc. thesis, Laurentian University.

Gibbins S. F. M., Gibson H. L., Whitehead R. E. S., Watkinson D. H., and Jonasson I. R. ( 1994) Geology, geochemistry, stratigraphy and mechanism of emplacement of the Onaping Formation. Dowling area. Sudbury Structure, Ontario, Canada. Geol. Assoc. Mineral. Assoc. Canada Program with Abstracts. Vol. 19. A-4l (abstr.).

Grieve R. A. F. (1994) An impact model of the Sudbury Structure. In Proce'edings of the Sudbury-Noril'sk Symposium (ed. P. C. Lightfoot and A. J. Naldrett); Ontario Geol. Survey, Spec. Vol. $5,119-132$.

Grieve R. A. F., Stöffler D., and Deutsch A. (1991) The Sudbury Structure: Controversial or misunderstood? J. Geophys. Res. 96, 22753-22764.

Grieve R. A. F., Langenhorst F., and Stöffler D. (1996) Shock metamorphism of quartz in nature and experiment: II. Significance in geoscience. Meteoritics and Planetary Science 31, 6-31

Guy-Bray J. and Geological Staff (1966) Shatter cones at Sudbury. J. Geol. 47, 243-245.

Hildebrand A. R., Penfield G. T., Kring D. A., Pilkington M., Camargo Z. A., Jacobsen S. B., and Boynton W. V. (1991) A possi- ble Cretaceous-Tertiary boundary impact crater on the Yucatan peninsula, Mexico. Geology 19, 867-871.

Hörz F. (1965) Untersuchungen an Ries Gläsern. Beitr. Mineral. Petrogr. 11, 621-661.

Hüttner R. ( 1969) Bunte Trümmermassen und Suevit. Geologica Bavarica 61, 142-200.

Johns G. W. and Dressler B. O. ( 1995 ) The Sudbury Igneous Complex-An impact melt sheet? Lunar Planet. Sct. XXVI, 679-680.

Krogh T. E., Davis D. W., and Corfu F. (1984) Precise U-Pb zircon and baddeleyite ages for the Sudbury area. In The Geology and Ore Deposits of the Sudbury Structure (ed. E. G. Pye et al.); Ontario Geol. Survey, Spec. Vol. 1, 431-446.

Krogh T. E., Kamo S. L., Sharpton V. L., Marin L. E., and Hildebrand $\mathrm{A}$. R. ( 1993 ) U-Pb ages of single shocked zircons linking distal K/T ejecta to the Chicxulub crater. Nature 366, 731-734.

Krogh T. E., Kamo S. L., and Bohor B. F. (1996) Shock metamorphosed zircons with correlated $\mathrm{U}-\mathrm{Pb}$ discordance and melt rocks with concordant protolith ages indicate an impact origin for the Sudbury Structure. In Earth Processes: Reading the Isotopic Code (ed. A. Basu and S. Hart); Amer. Geophys. Union, Geophys. Monogr. 95.

Lange M. A. and Ahrens T. J. ( 1979) Impact melting in early lunar history. Proc. IOth Lunar Planet. Sci. Conf., 2707-2725.

Masaitis V. L., Mikhaylov M. V., and Selivanovska T. V. (1976) The Popigay meteorite crater. NASA Technical Translation F16900.

Melosh H. J. (1989) Impact Cratering-A Geologic Process. Oxford Univ. Press

Milkereit B., Green A., and Sudbury Working Group (1992) Deep geometry of the Sudbury Structure from seismic reflection profiling. Geology 20, 807-811.

Muir T. L. (1984) The Sudbury Structure: Considerations and models for an endogenic origin. In The Geology and Ore Deposits of the Sudbury Structure (ed. E. G. Pye et al.); Ontario Geol. Survey, Spec. Vol. 1, 449-489.

Muir T. L. and Peredery W. V. (1984) The Onaping Formation. In The Geology and Ore Deposits of the Sudbury Structure (ed. E. G. Pye et al.); Ontario Geol. Survey, Spec. Vol. I, 139-210.

Müller-Mohr V. ( 1992 ) Gangbreccien der Sudbury Struktur; Geologie, Petrographie und Geochemie der Sudbury-Breccie, Ontario. Kanada. Ph.D. thesis, Univ. Münster.

Naldrett A. J. and Hewins R. H. (1984) The main mass of the Sudbury Igneous Complex. In The Geology and Ore Deposits of the Sudbury Structure (ed. E. G. Pye et al.); Ontario Geol. Survey, Spec. Vol. 1, 235-251.

Naldrett A. J., Hewins R. H., Dressler B. O., and Rao B. V. ( 1984) The contact Sublayer of the Sudbury Igneous Complex. In The Geology and Ore Deposits of the Sudbury Structure (ed. E. G. Pye et al.); Ontario Geol. Survey, Spec. Vol. 1, 253-274.

Peredery W. V. (1972a) The origin of rocks at the base of the Onaping Formation, Sudbury, Ontario. Ph.D. thesis, Univ. Toronto.

Peredery W. V. ( $1972 \mathrm{~b})$ Chemistry of fluidal glasses and Melt Bodies in the Onaping Formation. In New Developments in Sudbury Geology (ed. J. V. Guy-Bray); Geol. Assoc. Canada, Spec. Paper 10, 49-59.

Peredery W. V. and Morrison G. G. ( 1984 ) Discussion of the origin of the Sudbury Structure. In The Geology and Ore Deposits of the Sudbury Structure (ed. E. G. Pye et al.); Ontario Geol. Survey, Spec. Vol. 1, 491-511.

Pye E. G., Naldrett A. J., and Giblin P. E., eds. (1994) The Geology and Ore Deposits of the Sudbury Structure. Ontario Geol. Sunvey, Spec. Vol. 1.

Rousell D. H. (1984) Onwatin and Chelmsford Formations. In The Geology and Ore Deposits of the Sudbury Structure (ed. E. G. Pye et al.); Ontario Geol. Suney, Spec. Vol. 1, 211-217.

Shanks W. S and Schwerdtner W. M. (1991) Structural analysis of the central and southwestern Sudbury Structure, Southern Province, Canadian Shield. Canadian J. Earth Sci. 28, 411-430.

Shanks W. S., Dressler B., and Schwerdtner W. R. (1990) New developments in Sudbury geology. International Workshop on Meteorite Impacts on the Early Earth. Perth. Australia. Lunar and Planetary Institute Contribution 746, 46 (abstr.). 
Sharpton V. L., Dalrymple G. B.. Marin I. I2.. Ryder G., Schuraytz B. C., and Urrutia-Fucugituchi J. (1992) New links between the Chicxulub impact structure and the ('retaceous/Tertiary houndary. Nature 359, 819-812.

Sigurdson H. and Sparks R. S. J. (1981) Petrology of rhyolitic and mixed magma ejected fiom the 1875 eruption of Askja, feeland. 1. Petrol. 22, 41-84.

Solomon S. C., Comer R. P.. and Head J. W. 11982) The evolution of impact basins: Viscous relaxation of topongraphic reliel'. J. Geephys. Res. 87, 3975-3992.

Speers E. C. (1957) The age relationship and origin of common Sudhury Breccia. J. Ceol. 65, 497-514.

Spray J. G. and Thompson I. M. (199.5) Iriction melt distribution in a multi-ring impact basin. Nature 37.3, 1.30-132.

Spudis P. D. (1984) Apollo 16 site geology and impact melts: implications for the geologic history of the lunar highlands. Pros: 15th Linar and Plamet. Sci. Comf. C95-CI07.

Spudis P. D. (1993) The (Eeology of Multi-Ring Impart Basins. Cambridge Univ. Press.

Stevenson J. S. (1960) Origin of Quartzite Breccial at the base of the Whitewater Series. Sudhury Batsin. Ontario. Intrmational Geol. Congress, 2Ith Session. Part 26. Supplementary Vol. Section 1 . $21,31-41$.

Stevenson J. S. (1961) Recognition of the Quartsite Breccia in the Whitewater Series, Sudbury Basin, Ontario. Trams, Roval Socity of Canada 60, 3rd Series, 57-66.

Stevenson J. S. (1972) The Onaping ash-flow sheet. Sudbury, Ontario. In New Developments in Sudmory Cieology ted. J. V. GuyBray); Geol. Assere. Camala, Spec. Paper 10, 124.

Stevenson J. S. (1990) The volcanic origin of the Onaping Formation. Sudbury, Canada. Textomphysics 171, 249257.

Stöffler D. (197la) Progressive metamorphism and classification of shocked and brecciated srystalline rocks at impact craters. $J$. Geophys. Res. 76. $5541-5.551$.
Stoffler D. (197/b) Coesite and stishovite: Identification and formation conditions in shock-metamorphosed rocks. J. Geophys. Res 76, $5474-5488$.

Stoffler D. (1972) Deformation and transformation of rock-forming minerals by natural and experimental shock processes. I. Behavior of minerats under shock compression. Fortschr. Mineral. 49, 50113.

Stöfler D. 1974 , Deformation and transformation or rock-forming minerals by nalural and experimental shock processes. II. Physical properties of hocked minerals. Fortschr. Mineral. 51, 256-289.

Stoffler D. (1984, Glasses formed by hypervelocity impact. J. Noncrostal. Sollids 67, 40,5-502

Stoffler D. and Langenhorst F. (1994) Shock metamorphism of quarty in nature and experiment: 1. Basic observation and theory. Meteritics 29, $155-181$

Stoffler D., Avermann M.-F.. Bischoff L., Brockmeyer P.. Deutsch A.. Dressier B. O. Lakomy R., and Müller-Mohr V. (1989) Sudbury. Canada: Remnant of the only multi-ring impact basin on Earth. Meterrition 24, 328 (abstr.)

Swisher C. (.. III el al. (1992) Coeval "Ar/ ${ }^{74}$ Ar ages of 65.0 million years ago from (hicxulub melt rock and Cretaceous-Tertiary boundary tektiles. Science 257,954-958.

Thompson L. M. and Spraty J. G. (1994) Pseadotachylitic rock distribution and genesis within the Sudbury impact structure. In Large Meteorite Imparts and Planefary Evolution led. B. O. Dressler et al.): (;SA Spec: Paper 293, 275-287.

Thomson JAS. F. 1957 , Cieology of the Sudbury Basin. Ontaria Dept. of Mines. Annial Report for 1956 65, Part 3, 1-56.

Williams H. (1957) Glowing avalanche deposits of the Sudbury Basin. Ontario 1)ept of Mines. Anmal Report for 19.56 65, Pant 3. 57.89 .

Wu J.. Milkercit B.. and Boerner D. (1994) Timing constraints on deformation of the Sudbury impact structure. Camadiall J. Earth Sci. 31, 1654 -1660). 